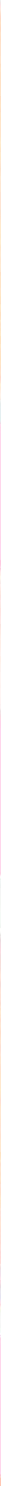

\title{
Micorrizas Arbusculares
}

“APLICACIÓN DE CIENCIA, TECNOLOGÍA E INNOVACIÓN EN EL CULTIVO DEL CAFÉ AJUSTADO A LAS CONDICIONES PARTICULARES DEL HUILA"

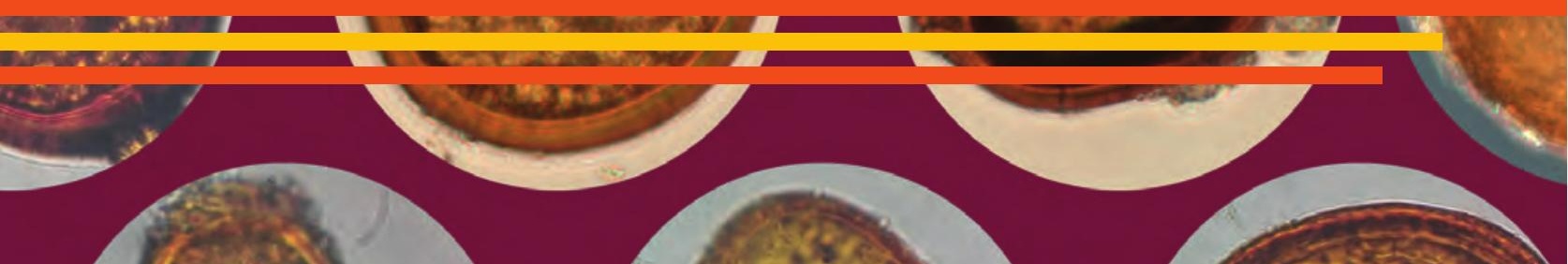




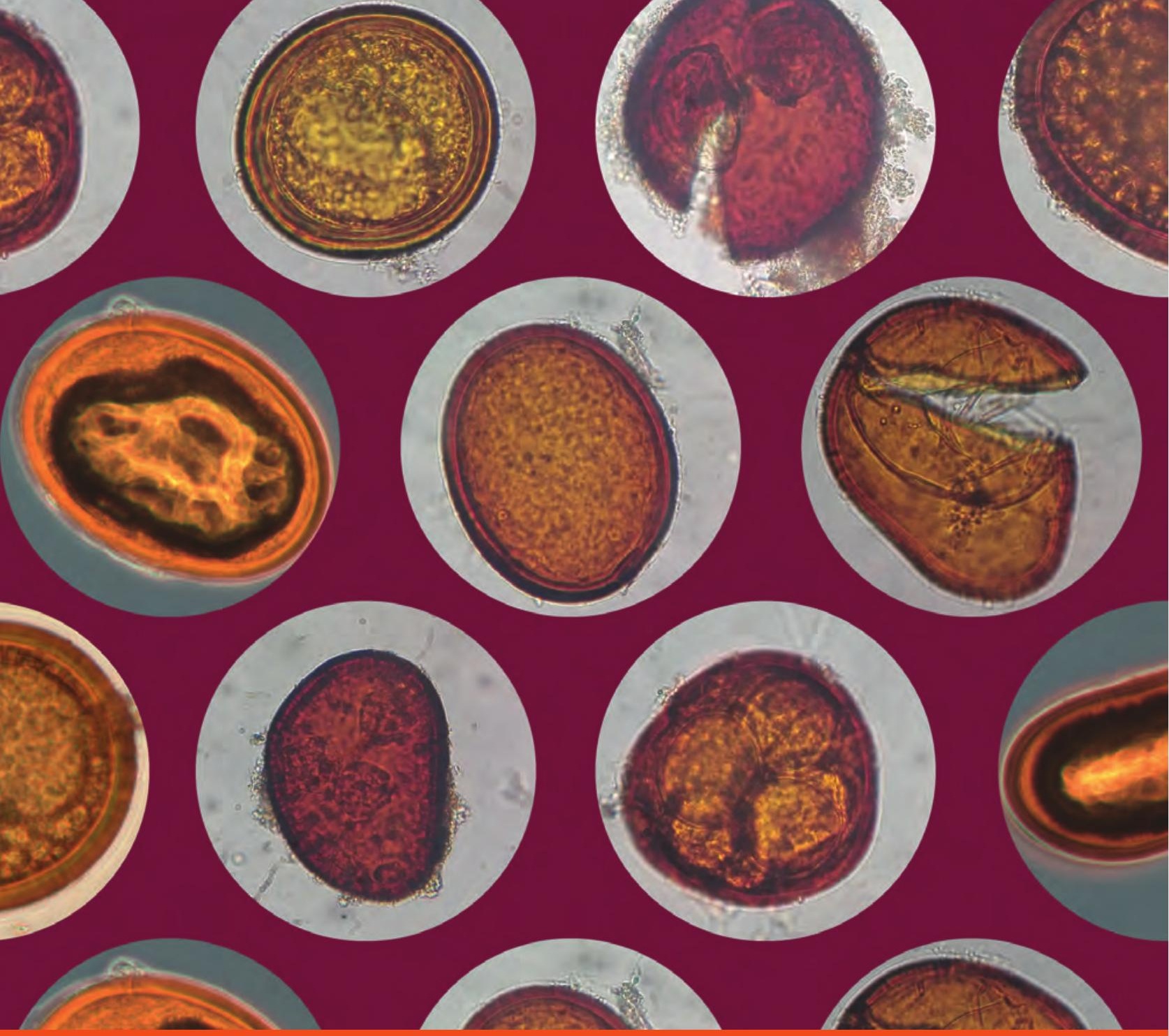

Carlos Alberto Rivillas Osorio MSc. Investigador senior

Carlos Mario Calle

MSc. Asistente de investigación

Carlos Ariel Ángel Calle

Ph.D. Investigador Científico III

Disciplina de Fitopatología

Cenicafé

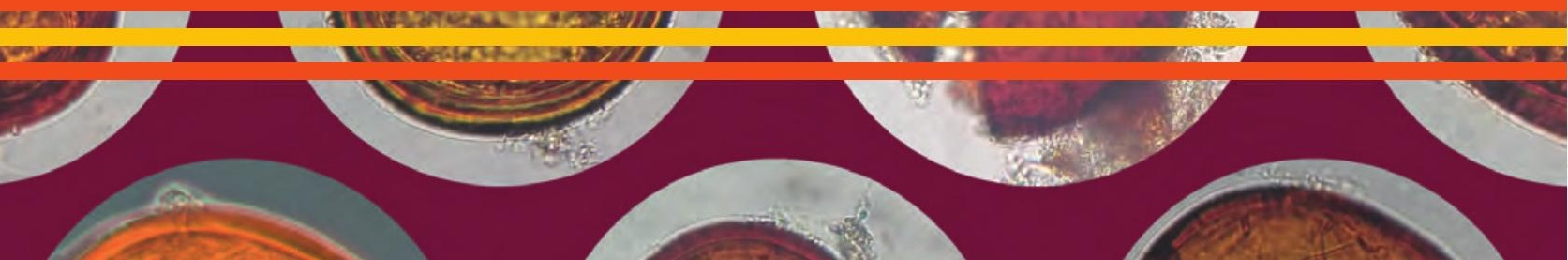


Los suelos constituyen uno de los mayores reservorios de biodiversidad, y los organismos del suelo desempeñan una función clave en la prestación de muchos servicios ecosistémicos (Organización de las Naciones Unidas para la Alimentación y la Agricultura- FAO 2017). Actualmente el uso de microorganismos benéficos en la agricultura juega un papel importante para la sostenibilidad de los ecosistemas; por ello, se ha incrementado el uso de bacterias promotoras de crecimiento vegetal, bacterias fijadoras de nitrógeno, microorganismos solubilizadores de fosfato y hongos formadores de Micorrizas Arbusculares - MA (Guerra, 2008).

La importancia de entender la microbiota del suelo radica en el hecho que todos los microorganismos que allí habitan realizan una serie de funciones clave para mantener la productividad, diversidad y estructura de las comunidades vegetales. De esta manera, las MA pueden tener una alta incidencia en la estabilidad de los ecosistemas y sistemas de producción donde las condiciones del suelo son extremas o limitantes (Garzón, 2016). Por ejemplo, suelos muy ácidos, muy básicos o por el tipo de textura (suelos arcillosos) que impedirían el normal desarrollo de las raíces.

En el marco del convenio "Aplicación de Ciencia, Tecnología e Innovación en el Cultivo de Café Ajustado a las Condiciones Particulares de la Caficultura del Huila" y en relación a la subactividad "Aislamiento, identificación y funcionalidad de micorrizas arbusculares aisladas del departamento del Huila", se ofrece a los caficultores del departamento, este capítulo que contribuye a conocer qué son las Micorrizas Arbusculares - MA, su importancia por la capacidad de formar una verdadera relación simbiótica/mutualista con las raíces de plantas de café, y el potencial ofrecido que se traduce en una serie de beneficios para la planta, principalmente en aspectos de crecimiento, desarrollo y fitosanidad.

Para ello, se seleccionaron con criterios técnicos, de manejo y de diversidad de los sistemas de producción de café, 105 lotes de café en los 35 municipios cafeteros del Huila, y en las seis zonas agroecológicas del departamento (ZAE). En general, se encontraron diferentes especies de MA en todos los suelos cafeteros del Huila, con rangos entre 5 y 2.392 esporas nativas por $100 \mathrm{~g}$ de suelo, con porcentajes de colonización de las MA en las raíces de café entre 1\% y 51\%. Del estudio, se seleccionaron 13 inóculos nativos de MA provenientes de los municipios de Garzón, Elías, Isnos, Palestina, San Agustín, Timaná, Tarqui, La Argentina, La Plata y Colombia, representativos de las seis $Z A E$, a los cuales se les ha determinado su potencial con base en pruebas de laboratorio e invernadero, y los efectos positivos de las MA en el crecimiento y desarrollo de las plantas de café en pruebas de efectividad en almácigos con la variedad Cenicafé 1.

Estos avances generales son un indicativo de la presencia y la actividad biológica de estos hongos en los procesos de colonización sobre las raíces de las plantas, evidenciando una alta diversidad de MA asociadas a la rizosfera de plantas de café y de la necesidad de su conservación y aprovechamiento por la labor benéfica que están realizando. 


\section{¿Qué son las Micorrizas Arbusculares - MA?}

Micorriza hace referencia a la asociación simbiótica ("vivir conjuntamente dos o más organismos"), entre las raíces de las plantas y cierto grupo de hongos habitantes naturales del suelo. Es una relación mutualista, porque tanto los hongos como la planta hospedante se benefician (García, 2009). El hongo simbionte recibe carbohidratos de la planta, ya que es incapaz de realizar fotosíntesis, lo que sí hace la planta, y a cambio el hongo brinda a la planta varios beneficios reflejados en su crecimiento, sanidad y nutrición (Jaramillo, 2011). La palabra se origina de los vocablos griegos mycos (hongo) y rrhiza (raíz).

Una de las principales características de las micorrizas arbusculares es su capacidad de extenderse más allá de la zona de raíces (Figura 1). El hongo desarrolla toda una red de micelio con la capacidad de explorar el suelo, capturar nutrientes y agua para la planta.

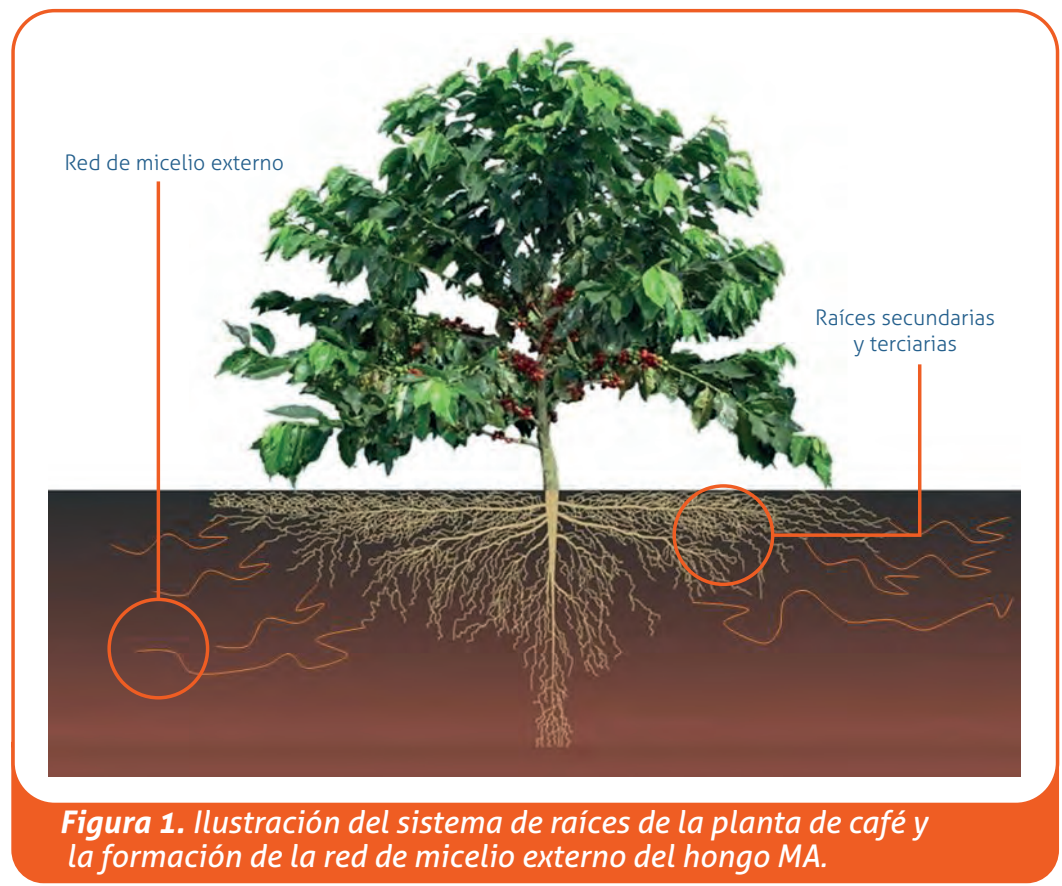

Las micorrizas arbusculares son capaces de crecer y extenderse dentro de las raíces sin causar síntomas de una enfermedad, por medio de unas estructuras llamadas hifas (Figura 2a) para formar arbúsculos y vesículas. Por el contrario, con el micelio externo, el hongo es capaz de extenderse más allá de la zona de raíces de las plantas con la función de explorar el suelo en la captura de nutrientes, en especial el fósforo. Estos hongos forman arbúsculos al interior de las raíces, con los cuales mantiene un intercambio bioquímico con la planta (Figura 2b). Las vesículas (Figura 2c) son estructuras donde se almacenan sustancias de reserva. Finalmente, estos hongos producen esporas que son células reproductoras, que permiten la dispersión y supervivencia del hongo por largo tiempo, como se presenta en la Figura 2d (Jaramillo, 2011). 


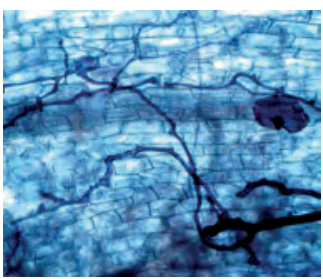

a.

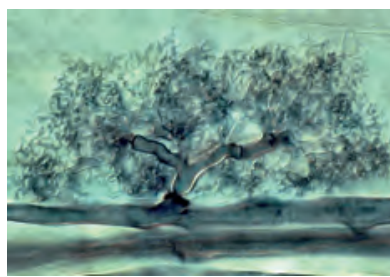

(b.)

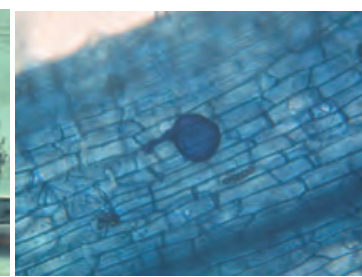

c.

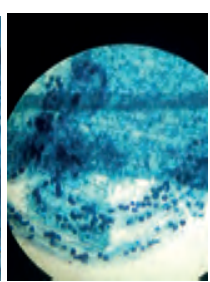

d.

Figura 2. Micorrizas arbusculares. a. Hifas al interior de la raíz; b. Arbúsculo (Peterson et al., 2004); c. Vesícula; d. Esporas.

Las micorrizas arbusculares pertenecen a un grupo de hongos habitantes naturales del suelo dentro de la división taxonómica Glomeromycota, que se compone de cinco órdenes diferentes, 15 familias, 38 géneros, entre los que se destacan Acaulospora spp., Gigaspora spp., Glomus spp., Sclerocystis spp. y Scutellospora spp., con aproximadamente 280 especies dentro de ellos (Jobim y Goto, 2016).

\section{Mecanismo de colonización de las micorrizas arbusculares}

Las MA se propagan en el suelo, principalmente mediante tres formas que se diferencian en su capacidad de supervivencia y potencial de colonización: 1) las esporas son las estructuras reproductivas y de resistencia de estos hongos; 2) los fragmentos de raíces micorrizadas de plantas preexistentes $y, 3$ ) las redes de hifas que sobreviven en el suelo. Estos propágulos, pueden mantener su capacidad de colonización incluso tras permanecer en el suelo seco durante varios meses. Cuando el hongo encuentra una raíz susceptible de colonizar, se generan señales químicas y estímulos que producen abundante ramificación del micelio del hongo, aumentando así las posibilidades de contacto con la raíz. Los sitios más habituales de penetración son los lugares más activos de la raíz; las MA no penetran por heridas ni colonizan raíces muertas, tampoco son patógenas o dañinas a las raíces (García, 2006).

\section{Funciones de las micorrizas arbusculares}

Son diversos los beneficios de la asociación simbiótica entre las MA y las plantas (Cano, 2011), tales como:

- Incremento en la superficie de absorción de agua y de nutrimentos.

- Incremento de la vida útil de las raíces absorbentes.

- Mejoramiento de la absorción de nutrientes y acumulación eficiente, especialmente, en el caso del fósforo.

- Solubilización de minerales que se encuentran en el suelo, facilitando su absorción por las raíces.

- Aumento de la capacidad fotosintética de la planta.

- Incremento de la tolerancia de las plantas a toxinas del suelo y a valores extremos de acidez del suelo.

- Disminución en el estrés causado por factores ambientales. 
Las MA constituyen un valioso recurso natural involucrado en numerosos servicios ecosistémicos, entre los que destacan aquellos presentados en la Tabla 1.

Tabla 1. Principales funciones de la simbiosis entre plantas y micorrizas(*).

Funciones

Funciones
Modifican la morfología de la raíz
desarrollando una red de micelio en el
suelo.

Secretan "glomalina", una sustancia capaz de aglutinar minerales y materia orgánica, aportando en la estabilidad de agregados, e infiltración de agua en el suelo.

\section{Captan el carbono que proviene de}

la planta, a la vez que incrementan la captación de minerales

Moderan los efectos contra el estrés
causado por factores abióticos (agua, luz,
temperatura, etc).

\begin{tabular}{c|l} 
temperatura, etc). & de nutrimentos minerales. \\
\hline $\begin{array}{c}\text { Protegen la raíz contra el ataque de } \\
\text { patógenos }\end{array}$ & $\begin{array}{l}\text { Incremento en la resistencia de la planta contra el estrés } \\
\text { causado por factores bióticos. }\end{array}$ \\
\hline $\begin{array}{c}\text { Modifican la fisiología y el metabolismo de } \\
\text { las plantas. }\end{array}$ & Protección y conservación de la biodiversidad
\end{tabular}

|*) (Neri y Villarreal, 2012).

\section{Importancia de las micorrizas arbusculares en sistemas productivos de café}

Las micorrizas arbusculares favorecen el crecimiento y nutrición de las plantas de café y su capacidad para disminuir la interferencia por arvenses agresivas o malezas (França et al., 2016). También, las MA en interacción con bacterias fijadoras de nitrógeno y hongos solubilizadores de fosfatos favorecen el crecimiento y desarrollo de las plantas y se incrementa la concentración de fósforo (P) en el tejido vegetal (Ibarra et al., 2014; Rojas et al., 2018).

Las MA incrementan la captación de nutrientes para la planta desde el suelo, donde la planta suministra al hongo carbohidratos para su metabolismo y el hongo facilita los nutrientes que la planta requiere, en ambientes donde la disponibilidad de estos nutrientes es restrictiva para el crecimiento vegetal, especialmente el fósforo (Gómez y Villate, 2010).

El fósforo es un elemento inmóvil en el suelo, y entre 95\% y 99\% del fósforo del suelo no está disponible para las plantas, de allí la importancia de las MA para su absorción. La adición de cantidades bajas de fertilizante fosfatado es compatible e incluso beneficia la simbiosis con la MA, ya que estimula el crecimiento de la raíz en su búsqueda, pero al incrementar la dosis se comienza a interferir la formación de la simbiosis, llegándose incluso a la inhibición de la colonización (Guerra, 2008).

Por ello, es importante disponer de un análisis de suelos para conocer la cantidad y disponibilidad de los diferentes nutrientes para el café, de tal manera que no se apliquen 
cantidades excesivas de fósforo en el suelo, donde existe una disponibilidad natural para su captación por parte de las MA, lo cual haría que no solo se incurrieran en costos innecesarios, sino en factores adversos para la permanencia de estos hongos en el suelo.

Las MA también son capaces de transferir nitrógeno $(\mathrm{N})$ del suelo circundante a la planta mediante su absorción, donde prefieren como fuente de $\mathrm{N}$ al amonio ( $\mathrm{NH}_{4}^{+}$) frente al nitrato (NO3- ); además, son capaces de absorber y transferir a la planta micronutrientes tales como zinc (Zn) y cobre (Cu) (García, 2006).

Las MA mejoran la sanidad de las plantas dado que pueden aumentar la tolerancia al ataque de patógenos mediante la conservación de la funcionalidad de la raíz durante la infección, y pueden compensar la pérdida de biomasa de las raíces mediante el crecimiento de las hifas del hongo en el suelo, al incrementar la superficie de absorción de las raíces. Se ha observado una competencia por el mismo espacio de la raíz, entre las MA y los patógenos de las raíces, y se ha detectado un incremento en ciertos compuestos involucrados en los mecanismos de defensa de la planta: fitoalexinas, compuestos fenólicos, aminoácidos, actividades enzimáticas de quitinasas, glucanasas y peroxidasas. Las MA también pueden inducir algunas reacciones de defensa en la planta, que implicarían la producción de metabolitos tóxicos para los hongos patógenos en los lugares de penetración, o la síntesis de compuestos que inhiben el desarrollo del patógeno y su infección (Peterson, 2010).

Plantas de café de la variedad Colombia inoculadas con las MA Entrophospora colombiana, Glomus manihotis y la bacteria Burkholderia cepacia, no permitieron que las raíces fueran atacadas por la llaga negra Rosellinia bunodes en la etapa de almácigo, y además evidenciaron un mayor crecimiento de las plantas de café (Castro y Rivillas, 2002). Similarmente, las plantas de café de variedad Caturra y una línea resistente a la roya, inoculadas tempranamente con las MA Glomus manihotis y Glomus fasciculatum presentaron una disminución de la severidad de la enfermedad de la mancha de hierro (Cercospora coffeicola Berk y Cooke) con respecto a las plantas que no tenían las MA (Guzmán y Rivillas, 2008).

De igual forma, las MA ayudan a reducir los efectos de los daños por nematodos. Plantas de café inoculadas con siete especies de MA nativas aisladas de cafetales en México e inoculadas posteriormente con estados juveniles y huevos del nematodo fitopatógeno Meloidogyne incognita, presentaron un menor volumen de raíces afectadas, las plantas se observaban aparentemente sanas y vigorosas en la parte área, y aunque el nematodo penetró en la raíz y la dañó, las hifas de las MA permitieron el paso de nutrimentos y así la planta logró su desarrollo. Las plantas de café micorrizadas en presencia de nematodos tuvieron desarrollo similar a las plantas sanas (Trejo, Ferrera, Sangabriel y Baeza, 2018).

\section{Establecimiento de germinadores de café con MA}

Es de especial cuidado desde el germinador el desarrollo de una raíz sana, ya que es el único órgano no renovable de la planta. La raíz es fundamental en el crecimiento, anclaje y la producción del cafeto, pero a la vez, es el órgano más susceptible a patógenos del suelo como el hongo Rhizoctonia solani que causa el volcamiento Damping-off o mal del tallito, ocasionando la muerte de la plántula, 
además de la presencia de otros patógenos como llagas radicales (Rosellinia spp.) del suelo que atacan las raíces desde etapas tempranas del cultivo (Gaitán y Rivillas, 2013).

Se entiende por inoculación introducir un ser vivo dentro de otro para brindarle mejores condiciones de vida a uno u otro; en muchas ocasiones ambos se benefician mutuamente (Pérez y Ortiz, 2015).

La inoculación de las MA en la etapa de germinador se realiza depositando el inóculo a 3,0 cm por debajo del nivel de las semillas con el fin que al germinar sus raíces entren en contacto con los propágulos del hongo (Rivillas, 2003). La inoculación de semillas de café en diferentes estados de desarrollo y en diversos sustratos con la endomicorriza Glomus manihotis mostró que es una actividad que repercute para las plantas de café en una fase posterior a la de germinador. Esta inoculación temprana de las MA genera efectos positivos para las plantas de café en una fase posterior a la del germinador, y la colonización por las MA se incrementa en la medida que avanza el crecimiento y desarrollo de la raíz ${ }^{1}$.

\section{Incorporación de micorrizas arbusculares en la etapa de almácigo}

Durante la etapa inicial de crecimiento de una planta de café es mayor el desarrollo de la raíz que la parte aérea, tendiendo a invertirse a medida que avanza el desarrollo de la planta, ya que se aumenta la parte área con relación a la raíz (Flórez, Ibarra, Gómez, Carmona, Castaño y Ortiz, 2013).

La etapa de almácigo ofrece el mejor período de tiempo para la incorporación o inoculación con micorrizas arbusculares en las plantas de café.

Los primeros efectos positivos en el crecimiento y desarrollo de las plantas de café se observan a partir de los tres meses después de la inoculación (Rivillas, 2003). Al realizar la inoculación de las MA desde el trasplante o establecimiento de la chapola en la bolsa, permite que el hongo se establezca y logre colonizar progresivamente las raíces de la plántula de café, para que cuando las plantas se lleven al sitio definitivo en el campo ya estén protegidas y en capacidad de continuar el proceso de colonización y expansión en la rizosfera del suelo. Es decir, plantas de café con una mayor capacidad de adaptación al entorno específico donde se establecerán.

Por ejemplo, la inoculación de las especies nativas de MA Glomus manihotis, Glomus fistulosum y Entrophospora colombiana en plantas de café durante el almácigo produjo crecimiento comparable a los obtenidos con la adición de compuestos orgánicos, como lombricompuesto, pulpa de café, cenichaza y gallinaza. Plantas de las variedades Caturra y Colombia inoculadas con las MA Acaulospora tuberculata, Glomus manihotis, Glomus mosseae y Scutellospora heterogama mostraron el efecto positivo sobre el crecimiento y desarrollo de las plantas, donde Glomus manihotis se comportó mejor, favoreciendo el crecimiento de las plantas y del sistema radical, seguida por Scutellospora heterogama (Rivillas, 2003).

${ }^{1}$ Rivillas O, C.A. 2003. Aislamiento y funcionalidad de las micorrizas arbusculares en la zona cafetera colombiana. Centro Nacional de Investigaciones de Café - Cenicafé. P:1-6. 


\section{¿Cuál es la dosis o cuánto inóculo de micorriza debe aplicarse en chapolas de café?}

Para cada planta o chapola de café pueden aplicarse entre 5,0 y 10,0 g de producto o inóculo nativo por planta por bolsa de $17 \times 23 \mathrm{~cm}$ (2,0 kg de suelo aproximadamente).

En el caso de formulaciones comerciales registradas, que cuenten con suficiente información y respaldo experimental, debe atenderse lo que indique la etiqueta del producto y la recomendación del Servicio de Extensión. La cantidad de inóculo depende también de la calidad del mismo y de la concentración de esporas por gramo de suelo, por lo que es importante revisar la información que proporciona el productor comercial, en cuanto al origen o procedencia de los inóculos nativos que estén disponibles, así como las licencias sanitarias y de registro que certifiquen la calidad y legalidad de los mismos.

\section{¿Cómo se inocula una micorriza en chapolas de café?}

- Para inocular las MA directamente sobre las raíces de las chapolas de café se necesita en primer lugar hacer los orificios en el suelo, lo suficientemente profundos para que las raíces no se doblen al introducirla, o si es del caso cortar cuidadosamente el extremo sobrante de la raíz.

- Posteriormente, el inóculo de 5,0 a 10,0 g de la MA se deposita en el orificio, se tapa con suelo y se aprieta para asegurar que haga contacto con las raíces y no queden espacios de aire que luego afecten el desarrollo de la raíz. El contacto del inóculo de la MA con las raíces de la planta es fundamental para facilitar una rápida y buena colonización de la micorriza.

\section{¿Cuánto tiempo tardan las micorrizas arbusculares en colonizar?}

Las micorrizas arbusculares pueden tardar entre 5 y 12 días en colonizar las raíces (Pérez y Ortiz, 2015).

\section{¿A qué edad de la planta deben aplicarse las micorrizas arbusculares?}

La mejor edad para inocular plantas de café se presenta en la etapa de almácigo, entre más jóvenes estén las plantas, mayor será el efecto al disponer de hongo que está colonizando las raíces aún en crecimiento.

\section{¿Cuál es la mejor época del año para incorporar las micorrizas?}

La incorporación o inoculación obedece a la programación que se determine para el establecimiento del almácigo de café, cuando se proyecta la siembra en el campo, para ello es importante consultar las épocas recomendables para la siembra de café en Colombia como lo indica Jaramillo (2016). 


\section{¿Cuáles son las condiciones del suelo más adecuadas para la incorporación de las MA?}

Para facilitar el manejo, inmediatamente se hayan inoculado las raíces con las MA, debe humedecerse el suelo contenido en las bolsas para almácigo, para proporcionar un medio lo suficientemente adecuado para el desarrollo de ambos. Los riegos que se realicen posteriormente obedecerán a las condiciones que en su momento se presenten en la zona (épocas secas o lluviosas), considerando siempre mantener los suelos sin sobresaturación de agua, pues tanto las MA como las plantas de café toleran mejor ambientes secos o ligeramente húmedos.

Para la incorporación de las MA en la etapa de almácigo es importante conocer la calidad química y física del suelo que se planea utilizar en el llenado de las bolsas. Es fundamental disponer de un análisis de suelos para verificar sus propiedades químicas y físicas en cuanto al pH, materia orgánica (MO), fósforo (P), nitrógeno (N), potasio (K), calcio (Ca) y la textura del mismo. Si los valores están dentro de los rangos normales para café no es absolutamente necesaria la adición de compuestos orgánicos (pulpa de café, lombricompuesto, gallinaza etc), para enriquecer el sustrato, ya que el mismo suelo es capaz de suplir los nutrientes a las plantas en esta etapa; solo se incorporaría el inóculo. Una característica de las MA es que actúan mejor en suelos deficientes o pobres en nutrientes, ya que estimulan la extensión de la red de micelio en el suelo para capturar nutrientes, cuando éstos ya se encuentran agotados en la zona de raíces de la planta.

Altos niveles de materia orgánica podrían actuar como inhibidor del efecto benéfico de la simbiosis (Alarcón y Ferrera, 1999). Por lo tanto, las MA son eficaces para incrementar la captación de nutrientes, particularmente fósforo y de este modo promover la acumulación de biomasa de muchos cultivos, en suelos que contienen bajo contenido de fósforo (Guerra, 2008).

\section{Duración y conservación de una micorriza arbuscular en el suelo}

La duración en términos biológicos puede ser indefinida, pero dependerá que existan los medios que necesita para sobrevivir: i) un suelo donde puedan expandirse y ii) una planta para colonizar. Pero los factores que pueden afectar la estructura y diversidad de las comunidades de MA son las poblaciones de otros microorganismos del suelo, la fertilización excesiva principalmente con fosfatos, el uso no controlado de fungicidas y herbicidas que pueden disminuir o hasta desaparecer el potencial micorrízico del sistema, y las prácticas agrícolas como la tala de bosques, fuego y labranza excesiva (Viasus, 2015).

Adicionalmente, el uso de fungicidas puede alterar la fisiología de la simbiosis, en especial los fungicidas sistémicos, por lo que es recomendable utilizarlos en las dosis recomendadas y solo cuando sea estrictamente necesario, de acuerdo con la recomendación de un ingeniero agrónomo.

Así mismo, la aplicación de nematicidas en altas dosis puede afectar la colonización micorrízica, el uso de ellos en dosis intermedias o bajas, además de evitar el daño por nematodos, no debería afectar la funcionalidad y efectividad de los hongos micorrízicos (Alarcón y Ferrera, 1999). Sin embargo, actualmente en Colombia no se dispone de una recomendación de aplicación de nematicidas de síntesis química para cultivos de café en el campo de forma curativa, y solamente se recomienda el uso de productos biológicos basados en los hongos Beauveria bassiana, Metarhizium anisopliae y Paecilomyces lilacinus aplicados de forma preventiva al suelo al momento del trasplante de la chapola (Gaitán, Rivillas y Salazar, 2013). 
El manejo racional e integrado de arvenses con la aplicación de herbicidas de síntesis química, favorece no solo la convivencia con otras especies de plantas que también son colonizadas por la MA, y no se afectan drásticamente en forma directa a las comunidades microbianas entre ellas a las micorrizas.

\section{Importancia de utilizar micorrizas arbusculares nativas}

La selección de microorganismos nativos de la región es indispensable para que existan mayores posibilidades de establecimiento y multiplicación de los mismos en el suelo. Esto se fundamenta en el hecho que la diversidad funcional de las MA puede depender de la procedencia de los aislamientos, más que de la especie del hongo como tal. Del mismo modo, variantes o morfotipos de la misma especie de MA, recolectados de diferentes sitios confieren diferentes beneficios fisiológicos a la misma especie de planta hospedante (López, Alarcón, Quintero y Lara, 2015). Tal adaptación de las MA les otorga la capacidad de desarrollarse en ambientes específicos de alta o baja fertilidad, tipo de textura del suelo, en ambientes o entornos condicionados al clima de la zona o de la región.

\section{Micorrizas arbusculares versus fertilización}

Las micorrizas arbusculares no sustituyen la fertilización de un cultivo. La planta de café al igual que cualquier otro ser vivo necesita nutrirse para crecer, desarrollarse y expresar su máximo potencial productivo. El medio que sustenta la nutrición es el suelo, sea natural o por adición de fertilizantes, y es allí donde las micorrizas arbusculares mejoran la "captura" de nutrientes para la planta.

\section{Calidad y tipo del inóculo de MA a incorporar}

Una de las presentaciones más comunes en el mercado son formulaciones de MA preparadas en suelo estéril, cuyos contenidos de esporas, micelio y fragmentos de raíces colonizadas constituyen el conjunto de propágulos más reproducidos. El inconveniente radica en los altos volúmenes de producción de inóculo que se requieren para aplicar micorrizas a los almácigos comerciales de cientos o miles de plantas.

Se acepta que fragmentos de raíces micorrizadas son el inóculo más efectivo, pero las esporas aisladas, por su capacidad de supervivencia y mayor tolerancia a las situaciones adversas, son las principales responsables de perpetuar las MA en suelo y en la planta. El inoculante se entiende como aquel producto que posibilita la introducción de microorganismos, en este caso de las MA. Para favorecer el crecimiento y desarrollo de las plantas, puede tener diferentes presentaciones, ya sea líquido o sólido en los que se utilizan sustratos como la turba, el carbón activado, aceites, alginatos y otros soportes orgánicos e inorgánicos (Viasus, 2015). Existen numerosos desarrollos en la producción de inóculos de MA comercialmente en el mercado, para todos ellos hay ventajas y desventajas asociadas. También se registran formulaciones o presentaciones de MA en geles como medio semilíquido para transportar las esporas, caracterizado por ser un medio inocuo y libre de patógenos, formulaciones de esporas en arcillas muy finas y comprimidos (pastillas), entre otros. 
Cualquier tipo de producto o inóculo comercial debe contar con los registros y permisos vigentes de las autoridades colombianas como el Instituto Colombiano Agropecuario (ICA), en algunos casos las licencias de la Autoridad Nacional de Licencias Ambientales (ANLA), entre otros, para su producción, importación, comercialización o distribución.

Siempre debe garantizarse la calidad física, química, sanitaria y biológica del producto, además de la inocuidad, en términos de ausencia de otros patógenos o contaminantes no deseados para los cultivos.

\section{Parámetros indispensables para la selección de un hongo micorrízico efectivo}

Una vez establecida la simbiosis con las MA, el cultivo actúa como facilitador de la esporulación o reproducción del hongo, siendo esta etapa muy importante para su posterior preservación. Los factores que más pueden afectar de forma negativa el desarrollo del hongo, especialmente en la etapa de esporulación, son la fertilización excesiva, el pH, la temperatura del suelo y la cantidad de agua disponible. Los parámetros indispensables para la selección de un hongo micorrízico efectivo son (Suárez, 2001):

- Habilidad para colonizar, absorber y transportar fósforo (P) del suelo hasta la planta.

- Habilidad para incrementar el crecimiento y desarrollo de la planta mediante una relación estable.

- Habilidad para persistir en el suelo (si es requerido) y producir propágulos.

- Habilidad para soportar los métodos de producción a gran escala y que los propágulos resistan y sobrevivan por tiempo prolongado.

\section{Micorrizas arbusculares en sistemas productivos de café en el departamento del Huila (2016 - 2019)}

En Colombia se han obtenido importantes logros en café con las MA, determinándose no solo una alta dependencia del café por las MA, sino también una alta diversidad al encontrarlas de forma nativa en los suelos cafeteros en distintas zonas (Rivillas, 2003). Con el propósito de contribuir al conocimiento de la diversidad y funcionalidad de las MA en el cultivo de café en el departamento del Huila, se describen cuatro etapas que se desarrollaron para la subactividad Microbiota, en el marco del convenio "Aplicación de ciencia, tecnología e innovación en el cultivo de café ajustado a las condiciones particulares de la caficultura del Huila", en la búsqueda y selección de inóculos promisorios para sistemas de producción de café en el departamento.

\section{Muestreos de campo para la obtención de micorrizas}

La búsqueda de inóculos nativos de micorrizas arbusculares implicó el análisis de los sistemas de producción, el manejo agronómico y el clima, los cuales son claves en la diversidad, distribución y efectividad de estos hongos en el suelo. 
Se destacan la altura sobre el nivel del mar, la precipitación, la pendiente del terreno, la edad del cultivo y la variedad de café sembrada para la totalidad de fincas muestreadas en la zona cafetera del departamento. Todos los análisis se realizaron soportados por las bases de datos del Sistema de Información Cafetera (SIC@), los registros y análisis de los Ecotopos Cafeteros, la Red Meteorológica Cafetera de la FNC y de la Disciplina de Agroclimatología de Cenicafé.

Se seleccionaron 105 lotes de café representativos de las seis Zonas Agroecológicas (ZAE), en los 35 municipios cafeteros del Huila, y para cada municipio se seleccionaron tres lotes en diferentes áreas (Figura 3).

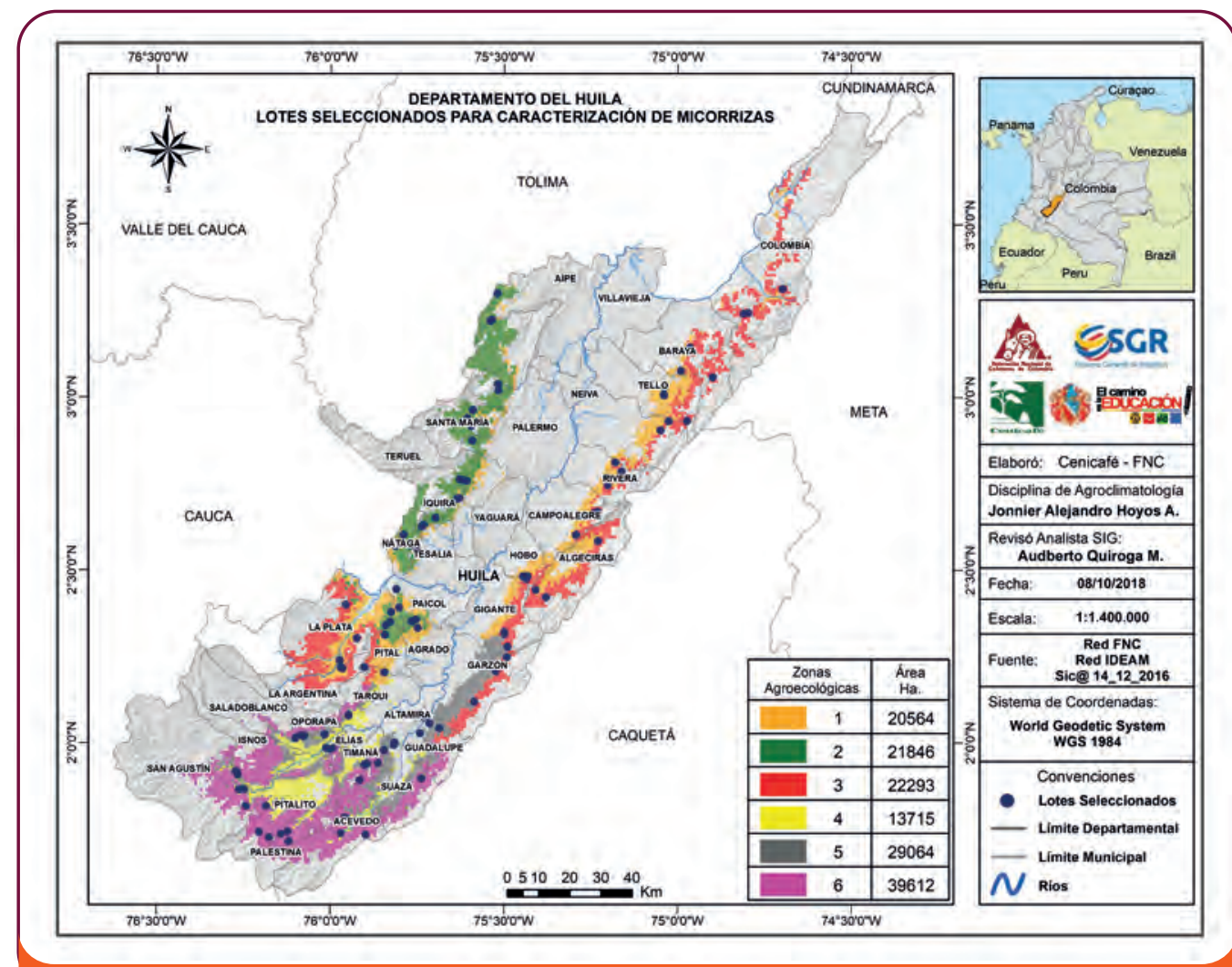

Figura 3. Distribución de lotes muestreados para las seis zonas agroecológicas del departamento del Huila (Fuente: Disciplina de Agroclimatología de Cenicafé).

Los muestreos en el campo consistieron en tomar submuestras de suelo con raíces a una distancia de 20, 30 y $50 \mathrm{~cm}$ alrededor del tallo del árbol de café, a una profundidad constante de $20 \mathrm{~cm}$ a partir de la base del tallo del árbol, para formar por cada árbol nueve submuestras (Figura 4a). En total se obtuvieron 270 submuestras para 30 árboles o sitios en lotes iguales o superiores a una hectárea y 180 submuestras para 20 árboles 0 sitios en lotes inferiores a una hectárea. Finalmente, se obtuvieron 19.890 submuestras en los 105 lotes de café visitados en esta investigación en el Huila. La Figura 4b ilustra el procedimiento llevado a cabo en el árbol para los muestreos, donde se obtuvo una muestra compuesta por lote de aproximadamente $7,0 \mathrm{~kg}$ de suelo. 
a.

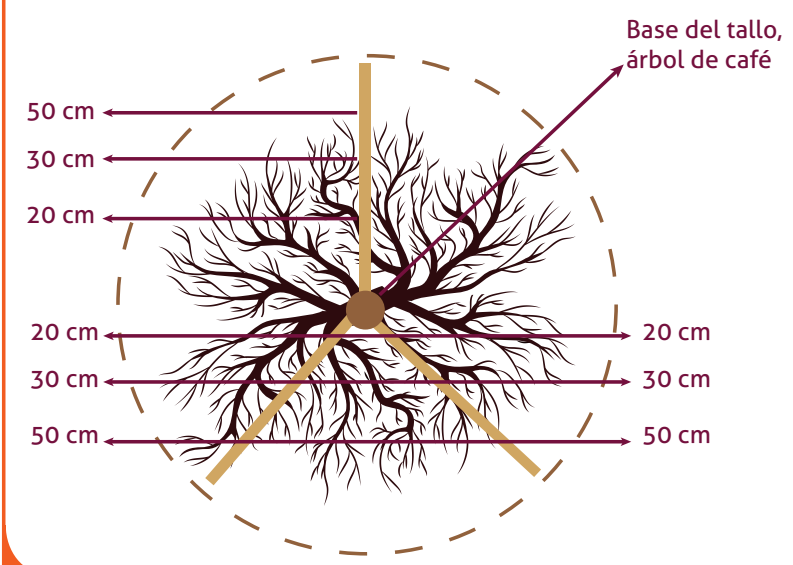

b.

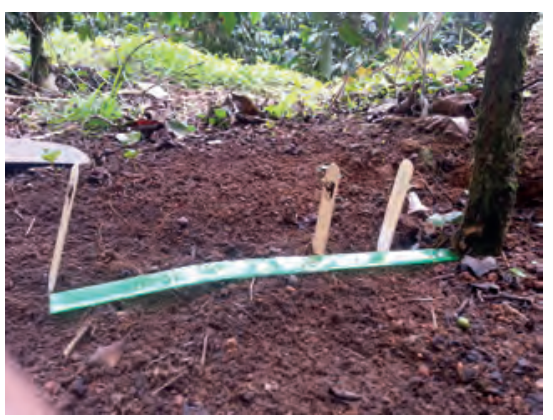

Figura 4. Toma de muestras de suelos. a. Esquema representativo de las distancias definidas desde la base del tallo de una planta de café para la toma de submuestras; $b$. Sitios trazados sobre el suelo en una planta de café en el campo, para la toma de submuestras para el aislamiento de MA.

En el laboratorio de micorrizas de Cenicafé se procesaron todas las muestras de suelo con raíces, empleando técnicas específicas para la extracción de esporas por gradiente de sucrosa (Figura 5a) y la tinción de raíces con azul de tripano (Figura 5b).

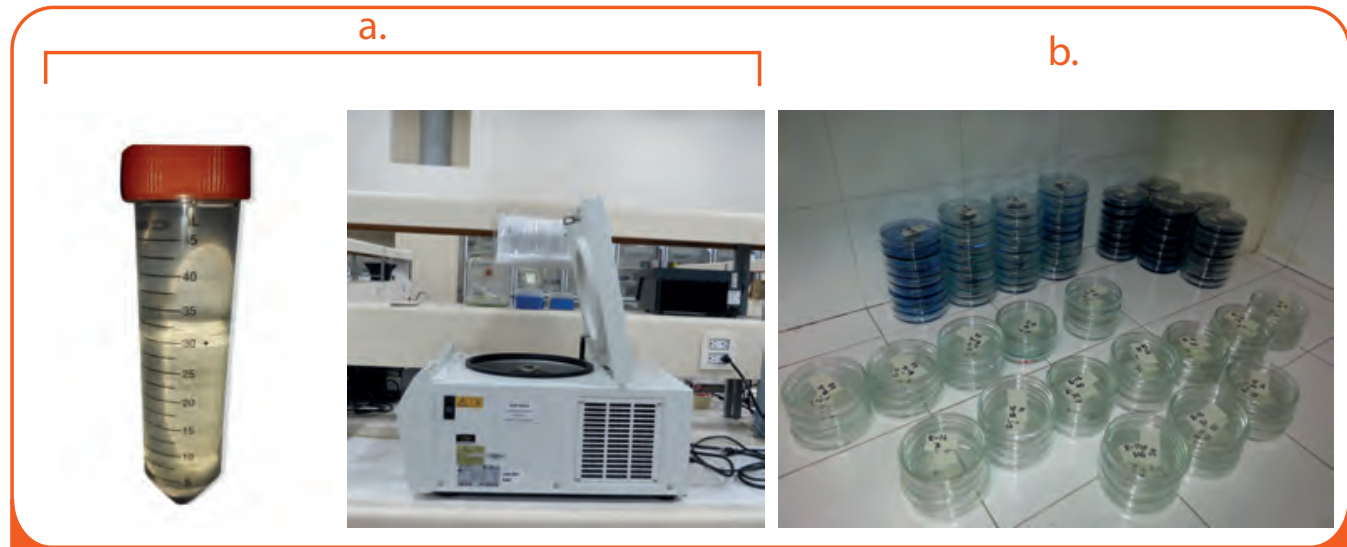

Figura 5. Métodos de laboratorio para la evaluación de micorrizas. a. Extracción de esporas de MA de suelos nativos con solución de azúcar al 75\%, para conteo expresado en número de esporas por $100 \mathrm{~g}$ de suelo; $b$. Proceso de tinción de raíces de café para determinar el porcentaje de colonización de las MA.

El proceso de tinción de raíces permitió visualizar al microscopio, las estructuras de colonización de los hongos MA (vesículas, arbúsculos, micelio inter e intracelular, esporas). Para la totalidad de muestras de suelo procesadas se evidenció una alta diversidad de MA asociadas a la rizosfera de plantas de café, encontrando esporas en diferentes estados de desarrollo, pertenecientes a diferentes géneros.

En la Tabla 2 se presentan los valores máximos y mínimos encontrados en el número de esporas por $100 \mathrm{~g}$ de suelo y en el porcentaje de colonización en fragmentos de raíces de café en las muestras originales tomadas en el campo. Es importante considerar 
que los efectos de la colonización no se deben a un solo hongo, sino a la interacción de varios de ellos que pueden estar asociados o compitiendo por los espacios en la raíz. La variabilidad observada es un indicativo de la presencia, diversidad y actividad de las MA en los procesos de colonización interna de las raíces de las plantas de café en el campo, en los diferentes lotes, en los 35 municipios del departamento de Huila.

\section{Tabla 2. Valores máximos y mínimos de la cantidad de esporas nativas de MA y porcentaje de colonización de raíces de muestras de los 35 municipios del departamento del Huila, agrupados en seis Zonas Agroecológicas.}

\begin{tabular}{|c|c|c|c|}
\hline Municipio & $\begin{array}{c}\text { Zonas } \\
\text { Agroecológicas }\end{array}$ & $\begin{array}{c}\text { Esporas (100 g/ } \\
\text { suelo) } \\
\text { Mínimo - Máximo }\end{array}$ & $\begin{array}{l}\text { Colonización de raíces (\%) } \\
\text { Mínimo- Máximo }\end{array}$ \\
\hline Neiva & $1-3$ & $53-1.038$ & $6-13$ \\
\hline Acevedo & $4-5-6$ & $140-708$ & $26-6$ \\
\hline Aipe & 2 & $313-608$ & $18-38$ \\
\hline Algeciras & 3 & $245-495$ & $16-27$ \\
\hline Altamira & $4-5$ & $20-112$ & $15-37$ \\
\hline Baraya & $1-3$ & $138-760$ & $16-33$ \\
\hline Campoalegre & $1-3$ & $353-548$ & $8-14$ \\
\hline Colombia & 3 & $112-765$ & $17-24$ \\
\hline Agrado & $1-2$ & $10-78$ & $27-36$ \\
\hline Pital & $1-2-3$ & $10-18$ & $17-50$ \\
\hline Elías & $4-6$ & $5-12$ & $26-36$ \\
\hline Garzón & $3-5$ & $23-37$ & $2-9$ \\
\hline Gigante & $3-5$ & $142-255$ & $16-27$ \\
\hline Guadalupe & 5 & $28-65$ & $1-18$ \\
\hline Hobo & 1 & $163-287$ & $8-20$ \\
\hline Iquira & $1-2$ & $33-138$ & $9-26$ \\
\hline Isnos & $4-5$ & $70-102$ & $18-47$ \\
\hline La Argentina & 1 & $360-1.752$ & $8-18$ \\
\hline La Plata & $1-2-3$ & $337-1.017$ & $17-34$ \\
\hline Nátaga & 2 & $1.328-1.787$ & $8-25$ \\
\hline Oporapa & $5-6$ & $20-82$ & $27-49$ \\
\hline Palestina & 6 & $232-398$ & $6-21$ \\
\hline Paicol & $1-2$ & $728-2.392$ & $15-25$ \\
\hline Palermo & 2 & $315-1.213$ & $25-32$ \\
\hline Pitalito & 6 & $100-250$ & $18-46$ \\
\hline Rivera & $1-3$ & $87-270$ & $23-33$ \\
\hline Saladoblanco & 5 & $23-77$ & $27-44$ \\
\hline San Agustín & $4-6$ & $117-513$ & $25-35$ \\
\hline Santa María & 2 & $270-357$ & $12-23$ \\
\hline Suaza & 6 & $232-732$ & $13-44$ \\
\hline Tarqui & $4-5$ & $47-58$ & $1-29$ \\
\hline Tello & 1 & $190-320$ & $13-29$ \\
\hline Teruel & 2 & $73-413$ & $12-38$ \\
\hline Tesalia & $1-2$ & $85-318$ & $19-37$ \\
\hline Timaná & $5-6$ & $13-105$ & $19-51$ \\
\hline
\end{tabular}


La cantidad de esporas y colonización de raíces también indican de forma general la posibilidad de encontrar diferentes tipos de inóculos promisorios para los diversos ambientes, manejos y tipos de suelos en el Huila, así como el potencial existente. Se reafirma la bondad y la presencia de las MA en todos los sistemas de producción y cultivos de café muestreados y en todos los suelos recolectados.

\section{¿Cómo se realiza el incremento de inóculos nativos?}

Constatada la presencia de MA en todas las muestras de suelo con raíces, se incrementaron los inóculos nativos, utilizando cultivos trampa en dos especies de plantas de fácil consecución y acceso para los agricultores como son el pasto braquiaria (Brachiaria decumbens Stapf.) y el kudzú tropical (Pueraria phaseoloides (Roxb.) Benth). Estas plantas al ser micotróficas obligadas (sin ser las únicas) necesitan de las MA para su adecuado desarrollo y crecimiento, y sirven de hospedantes alternos para incrementar los inóculos de esporas y propágulos de estos hongos, de forma rápida y en poco espacio en invernaderos. Para asegurar solamente el incremento de las MA nativas provenientes de los suelos muestreados, se esterilizó una parte de los suelos nativos sometiéndolos a altas temperaturas en autoclave. Posteriormente, se utilizaron materos de $2,0 \mathrm{~kg}$ en los cuales se dispuso una primera capa de suelo esterilizado, adicionando una capa de 50,0 g de suelo nativo sin esterilizar, y agregando finalmente otra capa de suelo nativo esterilizado para inducir la esporulación de los diferentes géneros de micorrizas arbusculares presentes en dichos suelos y finalmente sembrar las semillas de kudzú tropical y pasto braquiaria (Figura 6).

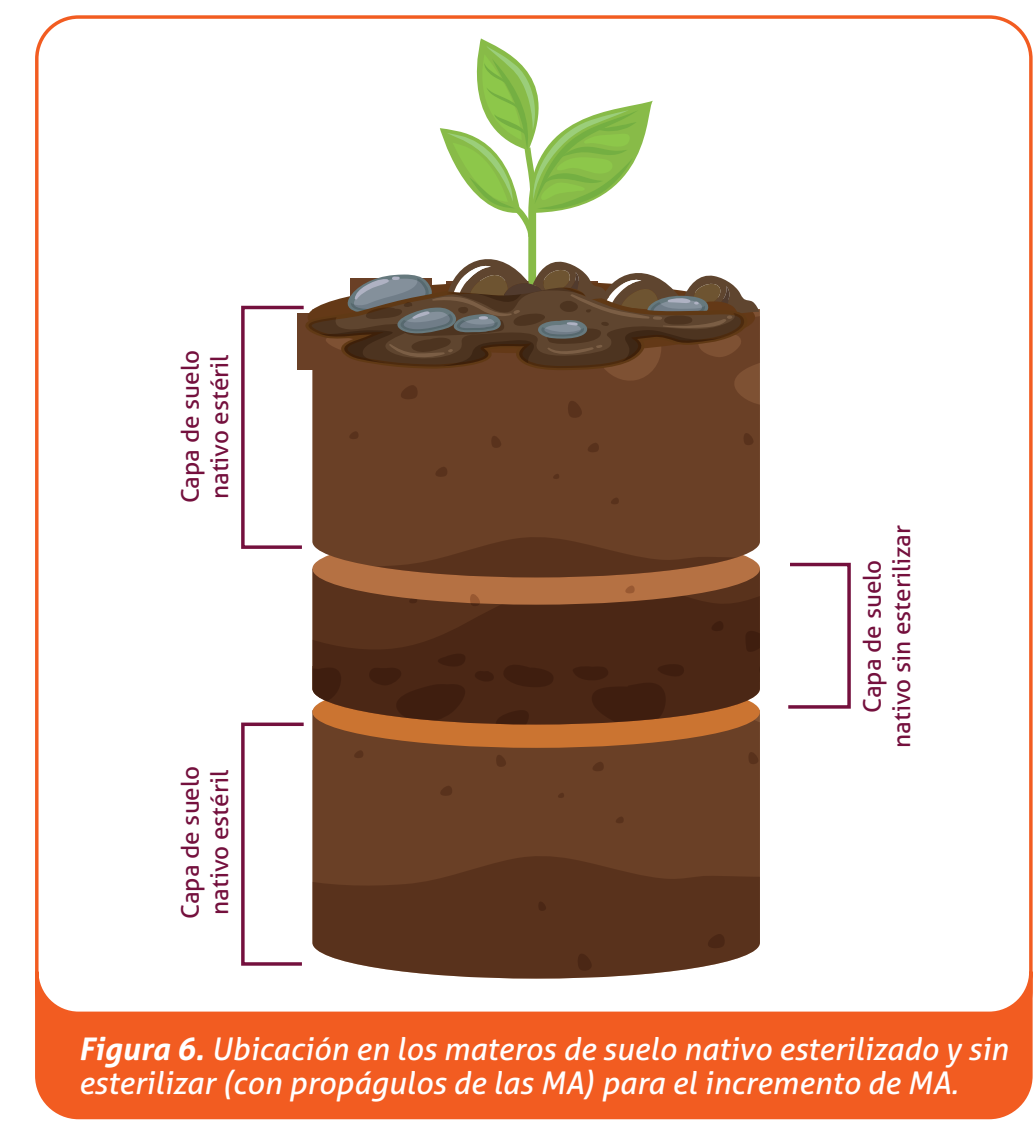


Para el establecimiento de los cultivos trampa, se realizaron los procedimientos generales que se utilizan para la siembra de materiales por semilla (Figura 7a), los cuales abarcan desde la consecución de las semillas, su lavado, proceso de germinación, siembra de las semillas germinadas en los materos y los cuidados que deben tenerse con los riegos, utilizando fuentes de agua de calidad, con el monitoreo de las plantas para evitar la presencia de arvenses, insectos plagas y de posibles enfermedades (Figura 7b). Igualmente, debe realizarse un manejo rutinario de estas plantas con la poda de la parte aérea cada 30 días. Después de 6 a 9 meses de establecidos los cultivos trampa se procede a su evaluación removiendo las plantas de sus materos, eliminando la parte aérea de las plantas y cortando las raíces en fragmentos pequeños para mezclarlas con el suelo (Figura 7c). Finalmente, se realizan los muestreos y la evaluación de cada uno de los materos para determinar la cantidad de esporas producidas y la colonización de las raíces del hospedante (Figura 7d).

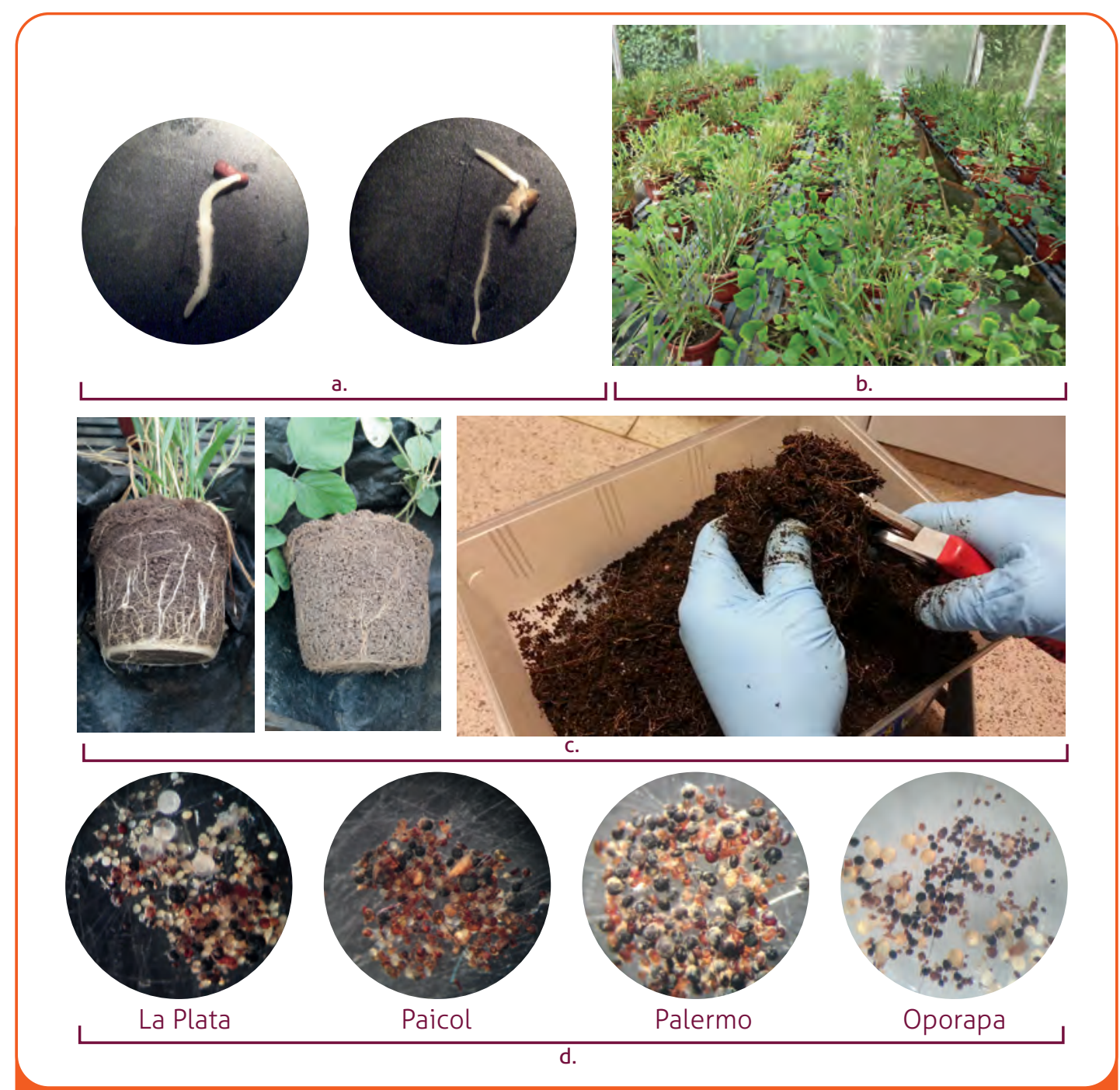

Figura 7. Establecimiento de cultivos trampa para la multiplicación de micorrizas arbusculares. a. Semillas germinadas de kudzú tropical Pueraria phaseoloides (leguminosa) y del pasto braquiaria Brachiaria decumbens (gramínea); b. Estado de cultivos trampa de kudzú tropical (derecha) y del pasto braquiaria (izquierda), para el aislamiento e incremento de micorrizas arbusculares en el vivero o casa de mallas; c. Plantas de kudzú tropical (derecha) y de pasto braquiaria (izquierda), procesadas para la evaluación del contenido de esporas. Plantas con muestras del municipio de Acevedo; $d$. Esporas nativas de MA incrementadas en pasto braquiaria y kudzú tropical. 
Con las MA en cultivos trampa se seleccionaron aquellas esporas que, por características morfológicas en cuanto a forma, color, tamaño, número de paredes y textura de la superficie eran contrastantes para formar inóculos puros (Figura 8a). De este modo se conformaron 143 cultivos puros o multiespóricos, los cuales se sometieron a incrementos en plantas de Brachiaria decumbens y Pueraria phaseoloides (Figura 8b). Para este caso, las plántulas se inocularon directamente en su sistema de raíces con las esporas nativas purificadas que se separaron por grupos similares u homogéneos.

Al tratarse de un cultivo puro, el suelo donde se va a establecer el cultivo debe pasteurizarse, para lo cual es necesario someterlo a temperaturas de $90^{\circ} \mathrm{C}$ por períodos de cuatro horas, mediante inyección de vapor de agua caliente desde una caldera, en ambiente cerrado.

En el caso de no contar con infraestructura para pasteurizar el suelo, se han adoptado prácticas de solarización en la finca, disponiendo capas delgadas de 20 a $30 \mathrm{~cm}$ de espesor de suelo sobre un piso de concreto o madera, desintegrando los terrones más gruesos. Luego, se cubre con plástico preferiblemente negro o translúcido, sellando los bordes de la era de suelo, pisando el borde con una hilera de suelo, ladrillos o troncos, para mantener hermético el sistema, sin romperse ni dejar entrar lluvia ni agua. De esta forma, durante el día, la radiación del sol calienta el plástico y el suelo, se incrementa la temperatura, se genera el vapor de agua caliente por encima de los 50 a $60^{\circ} \mathrm{C}$ durante el día que luego se enfría en la noche, lo cual va reduciendo progresivamente la mayor parte de microorganismos. Este proceso se mantiene durante 30 a 45 días dependiendo de las temperaturas, se voltea y revuelve el suelo y se repite otras dos veces, para un tiempo de solarización de dos a tres meses. Al final, el suelo seco solarizado se empaca en costales o bolsas limpias, para que no se vuelva a contaminar.

El resto del procedimiento de aclimatación, cultivo, mantenimiento y evaluación de los cultivos puros en el vivero es igual al descrito anteriormente (Figura 7b).

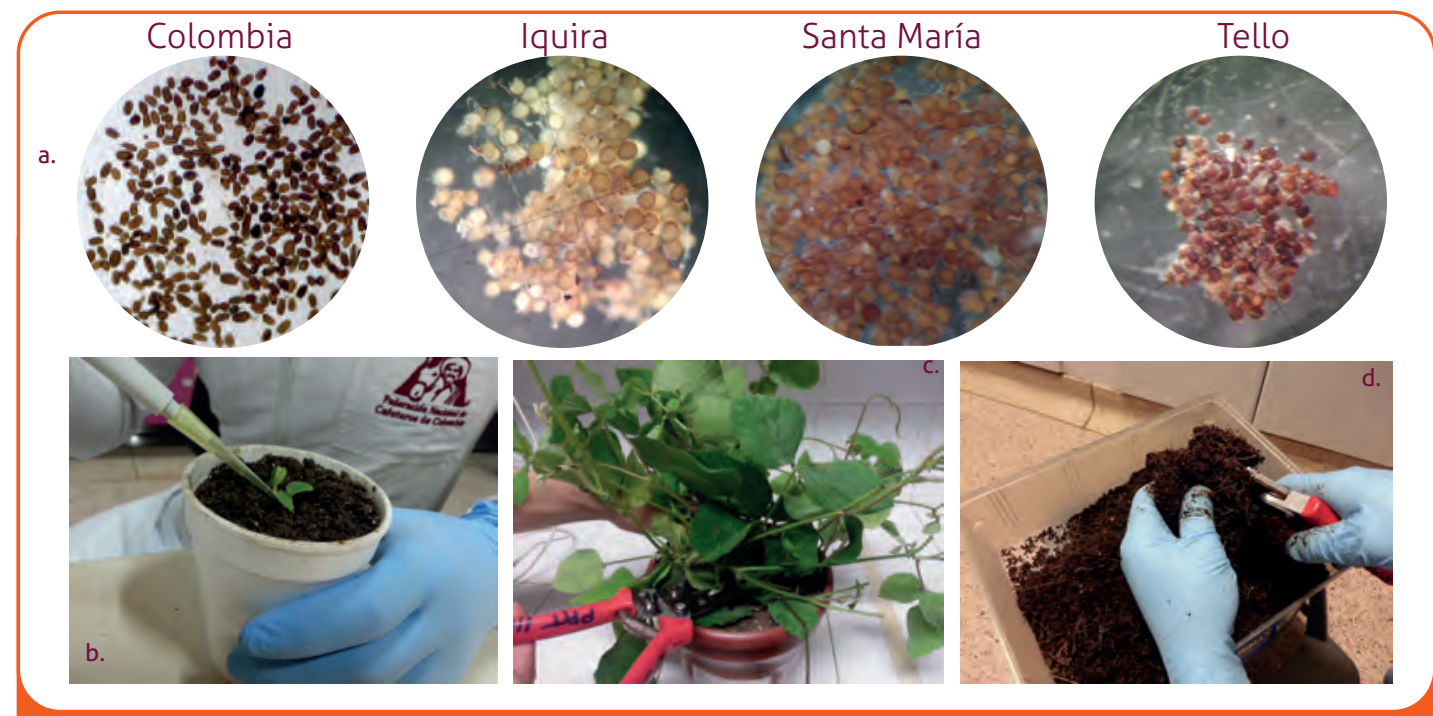

Figura 8. Multiplicación de inóculos puros de micorrizas arbusculares. a. Esporas puras de MA; b. Inoculación de esporas puras de MA en las raíces de plántulas de kudzú tropical; c. Corte de hojas y tallos de las plantas adultas de kudzú tropical, para evaluar en la rizosfera el inóculo puro incrementado; d. Preparación del inóculo compuesto, mediante corte fino de raíces para mezcla con el mismo suelo, que conforma el inóculo puro de MA para ser probado en plantas de café. 


\section{Selección de inóculos de MA con mayor potencial para el departamento del Huila}

A partir de la evaluación de los porcentajes de colonización y de la producción de esporas en el suelo de los cultivos multiespóricos establecidos en los viveros, se preseleccionaron 17 cultivos puros, y de allí quedaron finalmente 13, como los más promisorios para ser evaluados en pruebas de efectividad biológica en plantas de café (Tabla 3). La primera identificación de las esporas de estos cultivos correspondió a los géneros de MA Acaulospora spp., Entrophospora spp., Sclerocystis spp y Glomus spp., los cuales ya habían sido registrados como MA asociadas a cultivos de café y donde algunas de ellas ya habían mostrado efectos positivos en investigaciones previas de Cenicafé (Castro y Rivillas, 2002; Rivillas, 2003; Guzmán y Rivillas, 2008).

\begin{tabular}{|c|c|c|c|c|c|c|}
\hline \multirow{2}{*}{ Municipio } & \multirow{2}{*}{$\begin{array}{l}\text { Número de } \\
\text { identificación } \\
\text { Espora }\end{array}$} & \multirow{2}{*}{ ZAE } & \multicolumn{2}{|c|}{ Esporas (100 g/ suelo) } & \multicolumn{2}{|c|}{ Colonización de raíces (\%) } \\
\hline & & & $\begin{array}{l}\text { Brachiaria } \\
\text { decumbens }\end{array}$ & $\begin{array}{c}\text { Pueraria } \\
\text { phaseoloides }\end{array}$ & $\begin{array}{l}\text { Brachiaria } \\
\text { decumbens }\end{array}$ & $\begin{array}{c}\text { Pueraria } \\
\text { phaseoloides }\end{array}$ \\
\hline Tarqui & 4 & 4 & 15.767 & 17.260 & 4 & 8 \\
\hline \multirow{2}{*}{ Garzón } & 16 & 5 & 40 & 12.573 & 0 & 68 \\
\hline & 18 & 3 & 1.820 & 3.467 & 1 & 4 \\
\hline Elías & 26 & 4 & 0 & 1.820 & 0 & 0 \\
\hline Timaná & 28 & 5 & 7 & 1.153 & 0 & 15 \\
\hline Isnos & 32 & 5 & 0 & 6.907 & 0 & 37 \\
\hline Palestina & 36 & 6 & 0 & 2.300 & 0 & 33 \\
\hline San Agustín & 37 & 6 & 20 & 2.193 & 0 & 31 \\
\hline \multirow{2}{*}{ La Plata } & 52 & 2 & 20 & 4.593 & 0 & 24 \\
\hline & 54 & 3 & 153 & 2.173 & 0 & 16 \\
\hline \multirow{2}{*}{ La Argentina } & 59 & 1 & 0 & 1.787 & 0 & 12 \\
\hline & 59,1 & 1 & 0 & 1.167 & 0 & 27 \\
\hline Colombia & 85 & 3 & 7 & 493 & 0 & 6 \\
\hline
\end{tabular}

En la Tabla 3 se presenta el origen de los inóculos puros seleccionados para evaluar en almácigos de café y los resultados de los conteos promedio en el número de esporas producidas, como indicador de la capacidad de las MA de reproducirse en viveros. La colonización es un factor que permite inferir la capacidad del hongo de expandirse al interior de las raíces al observar los diferentes propágulos de colonización (vesículas, micelio interno y arbúsculos).

En cuanto al hospedante en la producción de esporas, las plantas de Pueraria phaseoloides fueron las más efectivas. La disponibilidad de los inóculos permite el establecimiento de las pruebas de efectividad biológica en plantas de café. La Figura 9 ilustra algunos de los inóculos nativos puros que se evalúan en café, representando las seis zonas agroecológicas del Huila. 


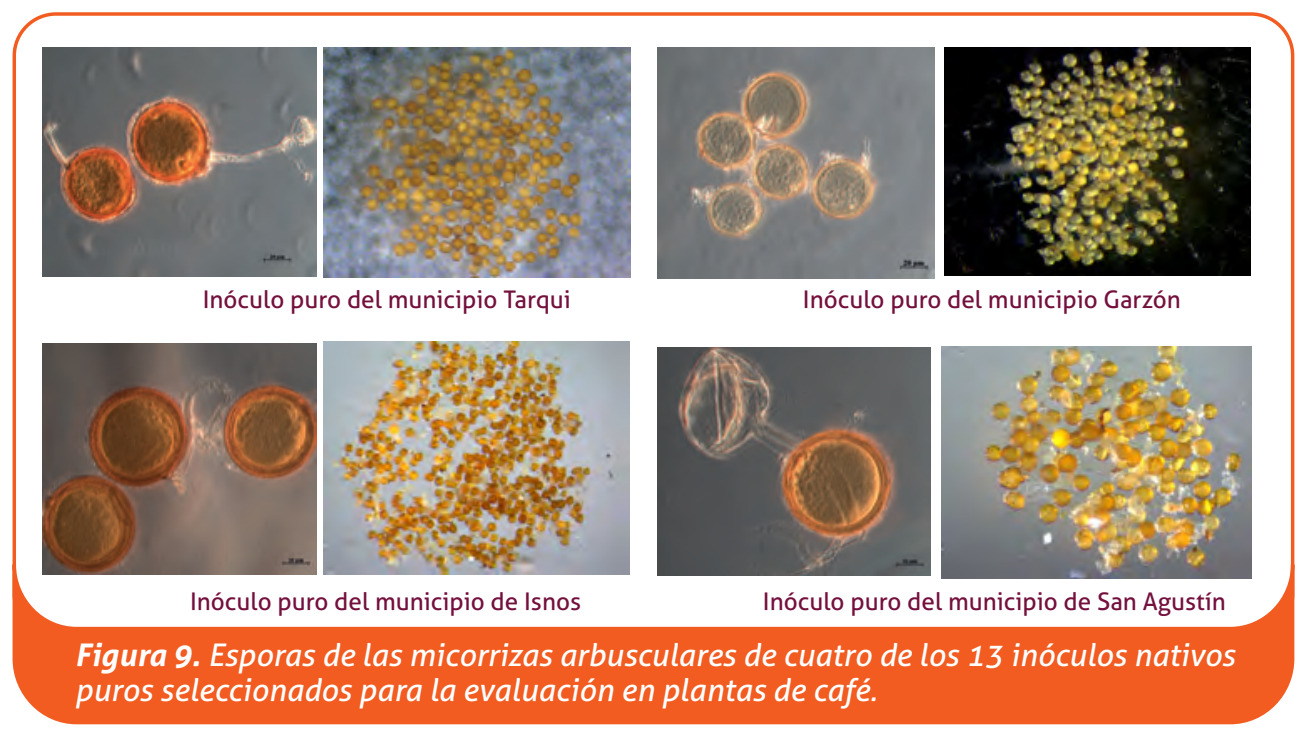

El hecho de obtener una alta producción de esporas de MA en el suelo y/o un alto porcentaje de colonización de raíces en las plantas de los cultivos trampa de kudzú tropical o de pasto braquiaria, no garantiza valores similares de colonización o que sean las mejores especies o inóculos para las plantas o cultivos de café. Esto solo puede determinarse mediante pruebas de efectividad en plantas de café en la misma región.

\section{Pruebas de efectividad biológica en plantas de café variedad Cenicafé 1}

El propósito fundamental de esta etapa fue evaluar en plantas de café la efectividad biológica de los 13 inóculos puros seleccionados a partir de su incremento en los cultivos multiespóricos, para determinar la capacidad de estos hongos de reproducirse tanto en el suelo como al interior del sistema de raíces del café. De esta forma se busca medir su efecto en el crecimiento, desarrollo y sanidad de las plantas, al compararlas bajo las mismas condiciones con testigos absolutos de plantas de café sin la aplicación de una MA y en iguales condiciones de manejo.

Para establecer las pruebas en el almácigo se tuvieron en cuenta la cantidad de inóculo disponible, la cantidad de suelo estéril o pasteurizado, la dosis de inóculo por bolsa y la disponibilidad de chapolas de café de la variedad Cenicafé 1 seleccionada. Se definió la siembra de 20 plantas de café, que se inocularon con 10,0 g de inóculo compuesto de esporas de la MA aislada y purificada y de suelo con raíces de cada uno de los cultivos puros seleccionados (con MA). En contraste, se establecieron otras 20 plantas de café var. Cenicafé 1 sin inóculo de MA como testigo absoluto (sin MA).

La Figura 10 ilustra de manera general el alistamiento de los materiales para llevar a cabo la inoculación de las MA en plantas de café de la variedad Cenicafé 1. Con base en las épocas recomendadas para la siembra de café en Colombia (Jaramillo, 2016), para la planeación con suficiente anticipación de todas las actividades y recursos, en el caso del departamento del Huila, el material de siembra debe estar listo en el mes de octubre, cuando ya están establecidas las lluvias para su siembra definitiva en el campo, lo cual significa que en el mes de febrero deben de iniciarse las labores para el establecimiento tanto del germinador como del almácigo. Es decir, para el principio de año debe tenerse el inóculo suficiente de las micorrizas arbusculares a utilizar. 


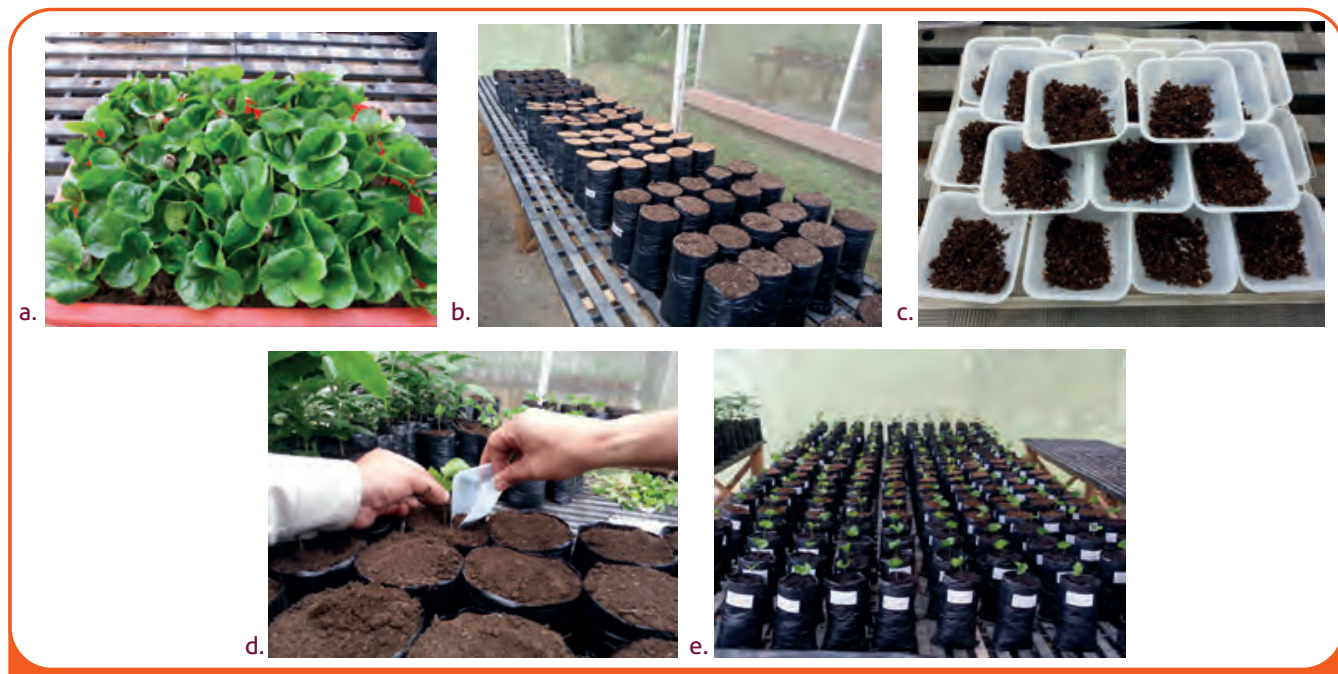

Figura 10. Materiales para llevar a cabo la inoculación de las MA en plantas de café. $a$. Producción y alistamiento de chapolas de café; b. Llenado de bolsas para almácigo; $c$. Inóculo puro de MA (suelo + raíces); d. Inoculación de la MA en cada chapola; e. Almácigo de café establecido.

Es importante considerar que los suelos utilizados en el almácigo corresponden a los suelos nativos de cada lote de café, de donde proviene cada uno de los inóculos de MA. Estos suelos se pasteurizaron previamente para evaluar su capacidad en la producción de esporas, como la capacidad de las MA seleccionadas en colonizar la raíz, y así determinar la respuesta de la planta en crecimiento y desarrollo.

\section{Evaluación de plantas de café en las pruebas de efectividad biológica de MA}

Las pruebas de efectividad biológica en plantas de café se basan en relacionar variables de crecimiento y desarrollo, que permitan entender el efecto que las micorrizas arbusculares ejercen sobre las plantas, al compararlas con testigos sin MA (Figura 11). Para ello, las variables que se midieron fueron: altura de la planta, diámetro del tallo, número total de hojas, número de nudos, ramas ortotrópicas o laterales primarias, número total de ramas, área foliar de la planta, distancia entre nudos, peso fresco y seco de la parte aérea (tallos y hojas), peso fresco y seco de las raíces, número de esporas/10 g de suelo, colonización de raíces (\%), análisis foliar (N-P-K-Ca-Mg-Fe).
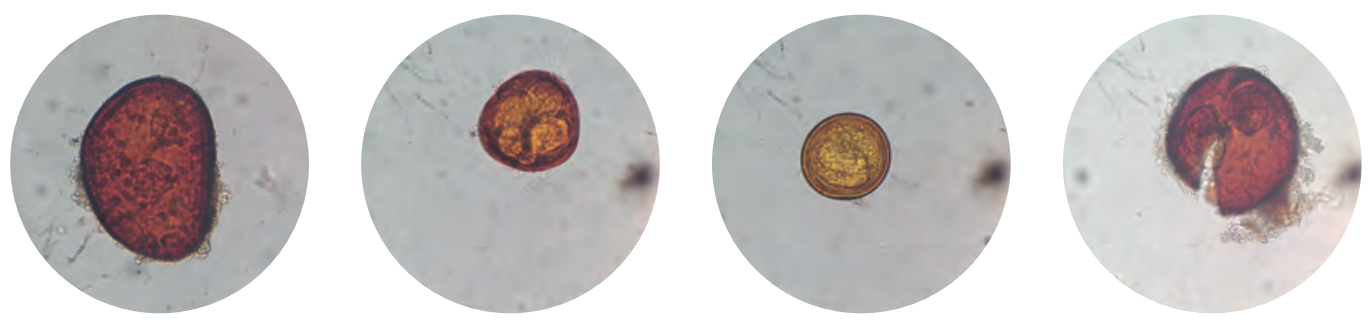

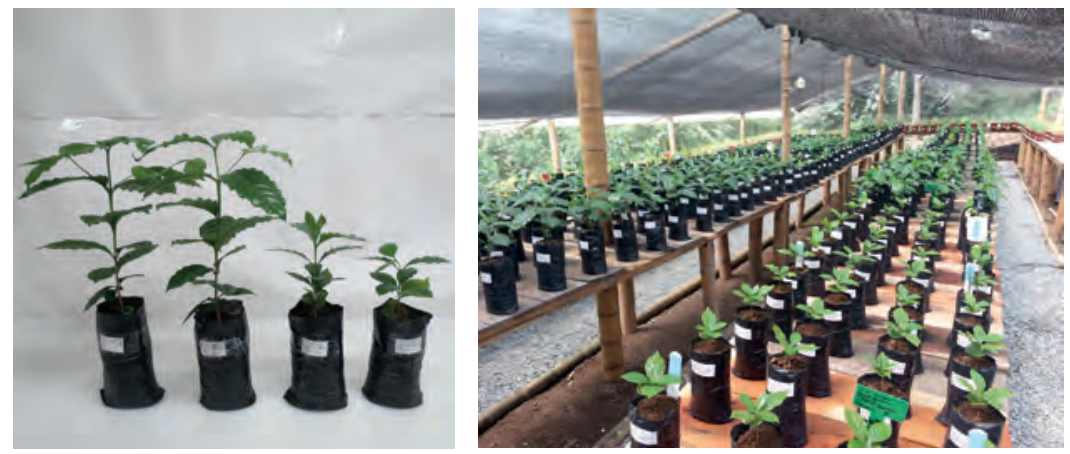

Figura 11. Pruebas de efectividad biológica de la aplicación de micorrizas arbusculares en plantas de café. a. Diferencias en el desarrollo entre dos plantas de café de la variedad Cenicafé 1, con MA (izquierda) y sin MA (derecha), en el municipio de La Plata; b. Almácigo de café con plantas inoculadas con MA (tratamientos) y plantas sin MA (testigos).

Las prácticas agronómicas en cuanto a la frecuencia de riegos, cantidad de agua aplicada por planta, fertilización, manejo de luminosidad y control de plagas y enfermedades fue igual entre plantas inoculadas con MA, y aquellas sin inocular con estos hongos. De esta manera, los efectos se centraron en las respuestas de las plantas a los inóculos de MA evaluados, teniendo como punto de referencia aquellas plantas que no recibieron el inóculo. Las plantas con y sin MA se evaluaron en su parte aérea y en raíces cuando completaron los 5,5 meses después de la siembra de la chapola en la bolsa, edad cercana para su trasplante al sitio definitivo en el campo.

En las Figuras 13 y 14 (a y b) se presentan los resultados parciales para la altura de la planta, área foliar por planta, peso seco de la parte aérea, y peso seco de la raíz.

Al analizar el crecimiento de la planta se observó un efecto positivo de varios de los 13 inóculos nativos sobre las plantas de café. Se observa que plantas con MA tienen altura y área foliar significativamente mayor para los inóculos números 26, 32, 37, 28, 4 y 54 con respecto a las plantas sin MA; mientras que para los inóculos 18, 16, 36, 85, 59 y 59,1 la diferencia en altura entre plantas con MA con respecto a las sin MA es muy poca o nula (Figuras 13 a y b).

Para variables de biomasa y su conversión en materia seca medida como peso seco de la parte área y de las raíces, se observaron diferencias significativas en plantas con MA para los inóculos 26, $32,37,28,4$ y 54, mientras que para el resto de inóculos la diferencia entre plantas con MA y sin MA fue menor o nula (Figuras 14 a y b).

En general, los inóculos que marcan la diferencia para estas cuatro variables de crecimiento, desarrollo y producción de biomasa entre plantas de café en almácigo con MA respecto a plantas sin MA son los números 32 (Isnos, ZAE 5), 37 (San Agustín, ZAE 6), 28 (Timaná, ZAE 5), 4 (Tarqui, Tratamiento al 75\%; ZAE 4) y 54 (La Plata, ZAE 3).
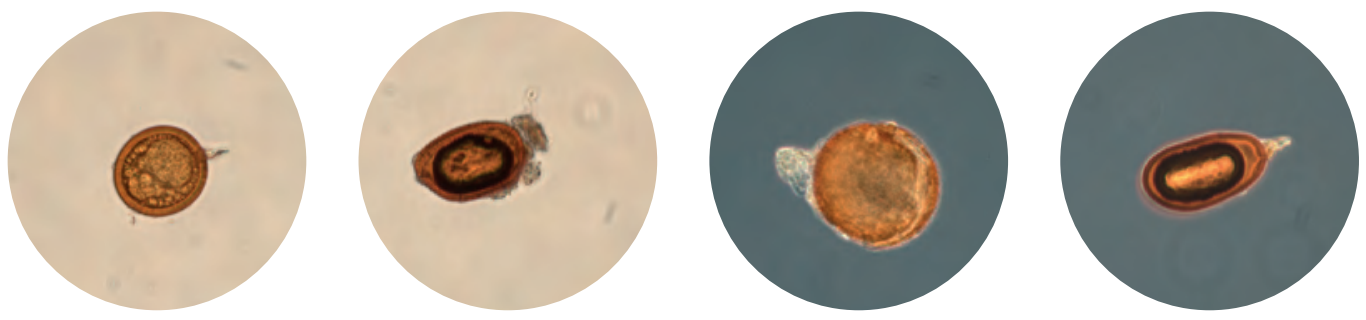
Altura de la planta $(\mathrm{cm})$

a.

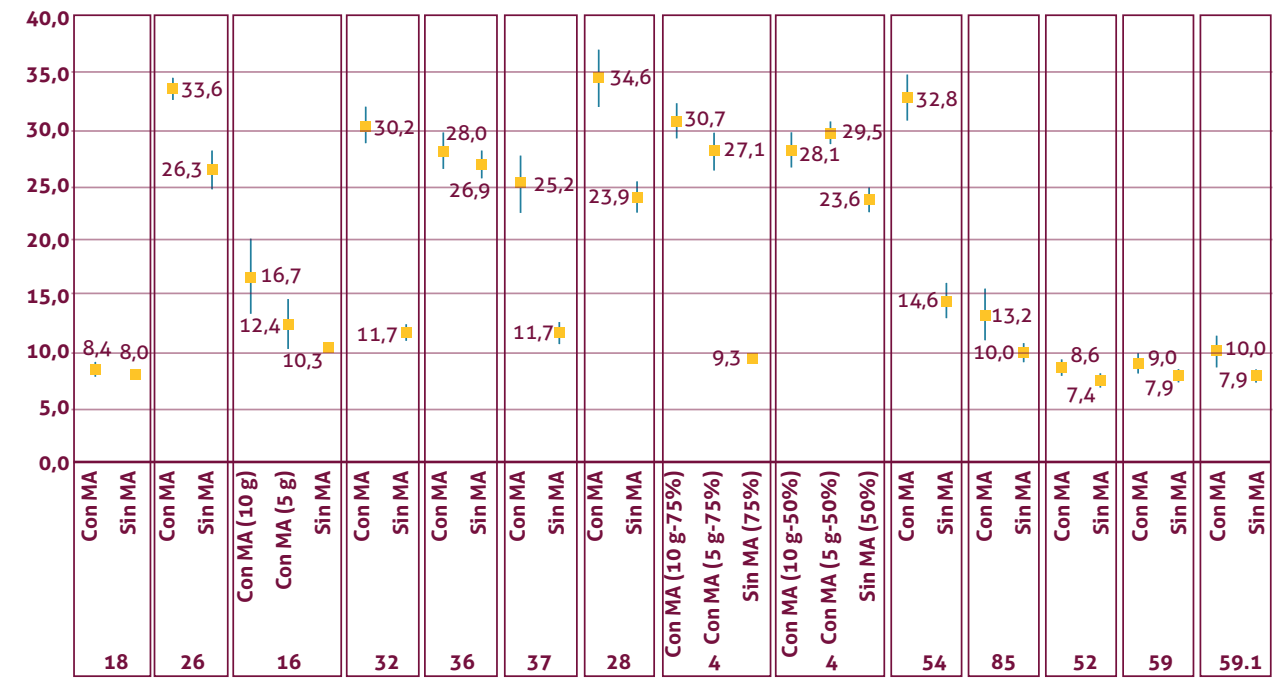

Área foliar $\left(\mathrm{cm}^{2}\right)$

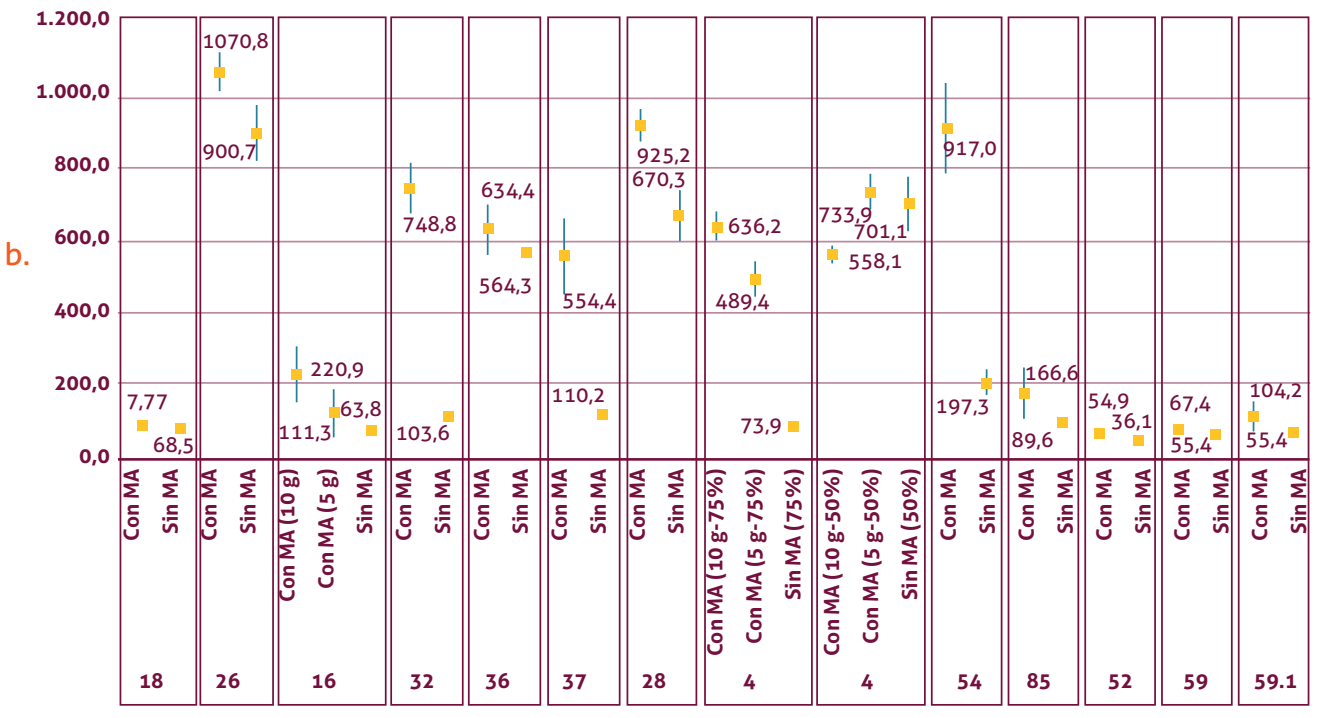

Figura 13. a) Altura de la planta (cm) y b) Área foliar por planta $\left(\mathrm{cm}^{2}\right)$ de plantas de café var. Cenicafé 1 con y sin MA, de los 13 inóculos seleccionados en el departamento del Huila. Intervalos de confianza al $95 \%$.

Nota: El número en la base de la figura corresponde a la identificación del inóculo puro de MA. Para el inóculo 4 se realizaron dos ensayos, uno con sustrato de suelo + turba al 75\%, con 5 y 10 gramos de inóculo/bolsa, y otro con sustrato de suelo + turba al 50\%. 
Peso seco de la parte aérea (gramos)

a.

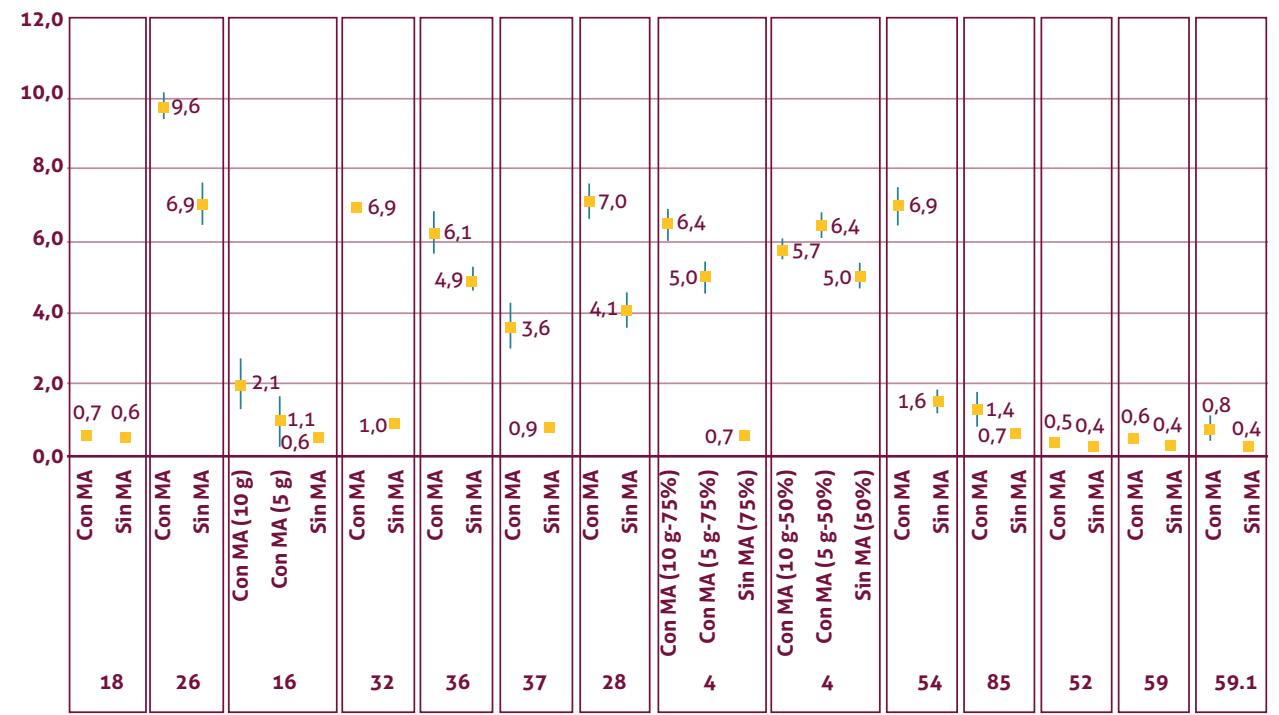

Peso seco raíz (gramos)

b.

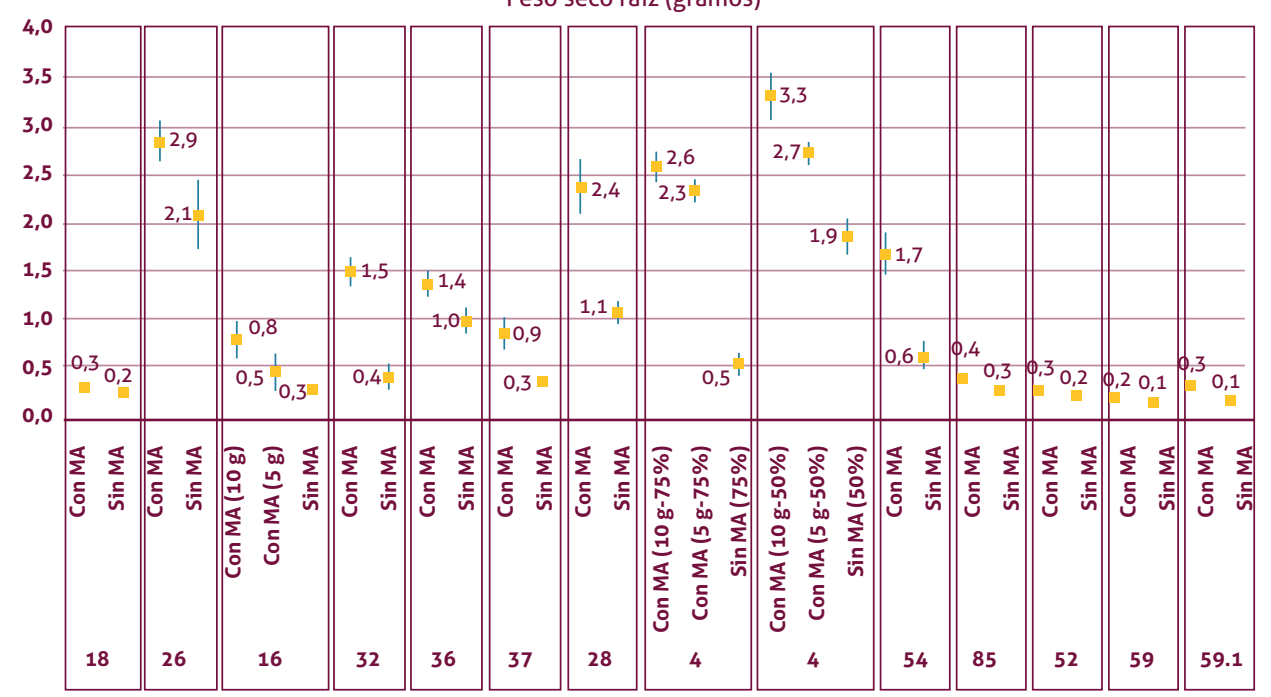

Figura 14. a) Peso seco (g) de la parte aérea de la planta (tallos y hojas); b) Peso seco de las raíces de plantas de café var. Cenicafé 1 con y sin MA de los 13 inóculos seleccionados en el departamento del Huila. Intervalos de Confianza al $95 \%$.

Nota: El número en la base de la figura corresponde a la identificación del inóculo puro de MA. Para el inóculo 4 se realizaron dos ensayos, uno con sustrato de suelo + turba al 75\%, con 5 y 10 gramos de inóculo/bolsa, y otro con sustrato de suelo + turba al $50 \%$. 
La mayor producción de biomasa medida como peso fresco y seco, tanto de la parte aérea como de las raíces de la planta, refleja la acción positiva de las MA; es decir, las plantas expresan una mayor capacidad para desarrollarse y acumular materia seca dependiendo de la capacidad de las MA para movilizar mayor cantidad de nutrientes y agua hacia la planta, que eventualmente la planta aprovecha.

De igual forma, las Figuras 13 y 14 (A y B) ilustran la variabilidad entre los tratamientos con MA y sin MA para un mismo suelo y entre suelos diferentes, para las variables altura, área foliar y peso seco de la parte aérea y de las raíces. Se notan los contrastes en valores que pueden indicar diferentes efectos de las MA sobre las plantas y de los tipos de suelos utilizados de donde se aislaron, en cada municipio y de las diferentes zonas agroecológicas. Es evidente el efecto positivo de las MA en las plantas en algunos de estos inóculos en sus suelos respectivos, cuando las condiciones de cultivo y manejo fueron siempre iguales entre los tratamientos con y sin MA.

La diversidad de las micorrizas arbusculares contribuye significativamente a la búsqueda, identificación y selección de inóculos, que por sus características y capacidad de adaptación a las condiciones específicas de los suelos de donde provienen, podrían emplearse en sistemas de producción de café. Sin embargo, solo las pruebas de efectividad en almácigos y luego en las etapas de levante y productiva en el campo determinarán el verdadero potencial y valor agregado que las MA le confieren a los sistemas de producción de café de un lote, finca o región. De esta forma, las MA podrán convertirse en un insumo biológico de importancia para ser incorporado dentro del manejo agronómico de la caficultura en el Departamento del Huila.

\section{Consideraciones}

- En los suelos de la zona cafetera del departamento del Huila existe un importante reservorio de microorganismos benéficos, entre los que figuran las micorrizas arbusculares, organismos perfectamente adaptados a las condiciones agroclimáticas de las seis Zonas Agroecológicas definidas para el departamento. Los 105 lotes muestreados en los 35 municipios cafeteros presentaron contenidos y colonización de raíces de café por las MA.

- Producto de un proceso de análisis de suelos, extracción, selección y multiplicación de esporas de MA se obtuvieron 13 inóculos nativos promisorios y con un alto potencial para seguir investigando sobre plantas de café. Estos 13 inóculos proceden de muestras de los municipios de La Argentina, La Plata, Garzón, Colombia, Tarqui, Elías, Timaná, Isnos, Palestina y San Agustín, de los cuales cinco de ellos generaron los mayores efectos positivos en altura de la planta, área foliar, peso seco de la parte aérea y de las raíces de plantas en almácigo de café var. Cenicafé 1.

- Las pruebas de efectividad biológica permiten evaluar variables de crecimiento, desarrollo y nutrición, para entender el efecto positivo que las micorrizas arbusculares pueden ejercer sobre las plantas de café, al compararlas con plantas sin la asociación con estos hongos. El caficultor con el acompañamiento del Servicio de Extensión puede realizar esta comparación para su respectivo suelo en la zona donde esté ubicado. No todos los inóculos de MA, sean nativos o comerciales, se comportan de la misma manera en todos los suelos. 
- Los microorganismos del suelo como las micorrizas arbusculares son un componente fundamental de la diversidad, estabilidad, productividad y sostenibilidad de los sistemas de producción de café en el Huila. Su conservación, incremento y aprovechamiento dependen de que se realicen buenas prácticas agrícolas, donde se haga un manejo integral del cultivo acorde a la zona y sistema de producción. La fertilización debe realizarse con base en los análisis de suelos para cada lote; el manejo de arvenses debe ser integral y racional, evitando el abuso de los herbicidas y manteniendo coberturas nobles. El manejo de plagas y enfermedades debe hacerse de forma oportuna, adecuada e integrada, para evitar excesos en fungicidas e insecticidas que pueden afectar al ambiente y la salud. La estrategia a seguir es "Más Agronomía, Más productividad".

- La información contenida en este capítulo le permite tanto a los caficultores como al Servicio de Extensión de la FNC y al público en general conocer qué son, por qué son importantes y para qué sirven las micorrizas arbusculares, y les brinda herramientas educativas y metodológicas para su obtención, conservación y aprovechamiento.

- Finalmente, se muestra el alto potencial de uso de las MA en almácigos de café para el departamento del Huila, para que estos inóculos sean un insumo de nuevas investigaciones, validaciones y trabajos de campo en las diferentes zonas y ambientes cafeteros del departamento, en la búsqueda de la productividad, la rentabilidad y la sostenibilidad de la caficultura del Huila por el bienestar de las familias cafeteras.

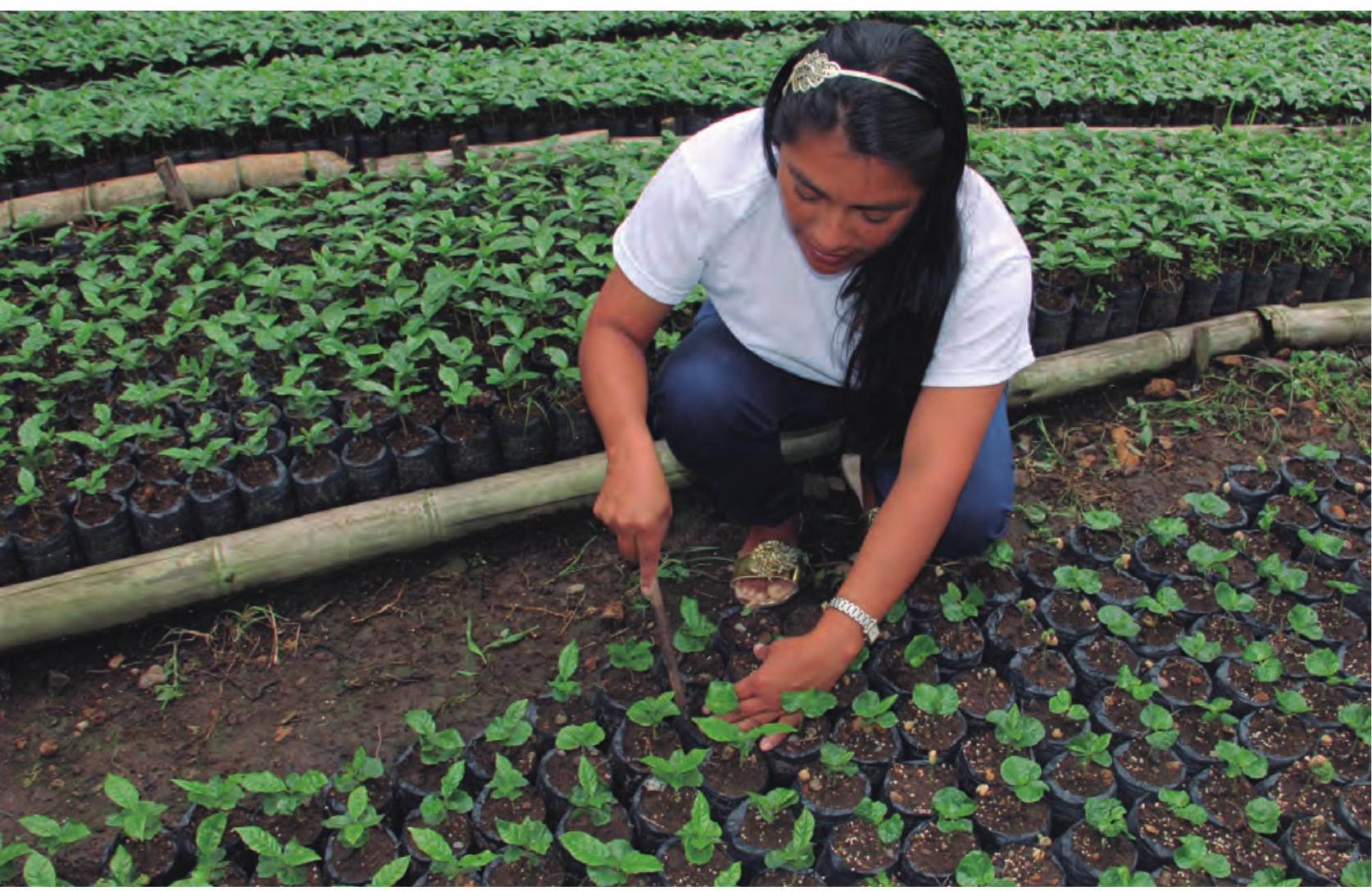




\section{Literatura citada}

Alarcón, A., y Ferrera Cerrato, R. (1999). Manejo de la micorriza arbuscular en sistemas de propagación de plantas frutícolas. Terra Latinoamericana, 17(3):1-13.

Cano, M. A. (2011). Interacción de microorganismos benéficos en plantas: micorrizas, Trichoderma spp. y Pseudomonas spp. Una revisión. Revista UDCA. Actualidad \& divulgación científica, 14(2):15-31.

Castro. T, A. M; Rivillas O, C.A. (2002). Entrophospora colombiana, Glomus manihotis y Burkholderia cepacia en el control de Rosellinia bunodes, agente causante de la llega negra del cafeto. Cenicafé, 53(3): 193-218.

FAO. (2017). Directrices voluntarias para la gestión sostenible de los suelos. Organización de las Naciones Unidas para la Alimentación y la Agricultura Roma, Italia: 1-26.

Flórez, C. P., Ibarra, L.N., Gómez, L.F., Carmona, C.J., Castaño, A., Ortiz, A. (2013). Estructura y funcionamiento de la planta de café. 2013. En Manual del Cafetero Colombiano. Tomo I. Investigación y Tecnología para la sostenibilidad de la caficultura (pp. 124-169). Chinchiná, Colombia: Centro Nacional de investigaciones de Café - Cenicafé.

França, A. C., Freitas, A. F. D., Santos, E. A. D., Grazziotti, P. H., y Andrade Júnior, V. C. D. (2016). Mycorrhizal fungi increase coffee plants competitiveness against Bidens pilosa interference. Pesquisa Agropecuaria Tropical, 46(2): 132-139.

Gaitán B, A.L., Rivillas O, C.A. (2013). Germinadores de Café. En Manual del Cafetero Colombiano. Tomo II. Investigación y Tecnología para la sostenibilidad de la caficultura (pp. 9-14). Chinchiná, Colombia: Centro Nacional de investigaciones de Café - Cenicafé.

Gaitán B, A.L., Rivillas O, C.A., Salazar G, L.F. (2013). Manejo Integrado de Almácigos. En Manual del Cafetero Colombiano. Tomo II. Investigación y Tecnología para la sostenibilidad de la caficultura (pp. 15 - 22). Chinchiná, Colombia: Centro Nacional de investigaciones de Café - Cenicafé.

García, M. H. (2009). Las micorrizas: una relación planta-hongo que dura más de 400 millones de años. In: Anales del jardín botánico de Madrid 66 (1): 133-144. Real Jardín Botánico.

García R., S. (2006). Efecto de las micorrizas arbusculares sobre la regulación de genes implicados en el metabolismo carbonado en plantas de tomate (Solanum esculentum). Universidad de Granada. Tesis doctoral, 246 p.

Garzón, L. P. (2016). Importancia de las micorrizas arbusculares (MA) para un uso sostenible del suelo en la Amazonia colombiana. Revista Luna Azul, (42): 1-19.

Gómez, M. R., y Villate, A. R. (2010). Señales de reconocimiento entre plantas y hongos formadores de micorrizas arbusculares. Corpoica Ciencia y Tecnología Agropecuaria, 11(1): 53-60.

Guerra S, B.E. (2008). Micorriza Arbuscular. Recurso microbiológico en la agricultura sostenible. Tecnología en Marcha, 21(1): 191-201.

Guzmán, O. A., y Rivillas, C. A. (2008). Relación de Glomus manihotis y Glomus fasciculatum con el crecimiento de plantas de café y la severidad de la mancha de hierro. Cenicafé: 58(3):236-257. 
Ibarra - Puón, J. C., Aguirre - Medina, J. F., Coss, L. D., Cadena - Iñiguez, J., y Zavala - Mata, G. A. (2014). Coffea canephora (Pierre) ex Froehner inoculado con micorriza y bacteria fijadora de nitrógeno en vivero. Revista Chapingo. Serie horticultura, 20(2): 201-213.

Jaramillo, A. (2016). Épocas recomendadas para la siembra del café en Colombia. Federación Nacional de Cafeteros de Colombia. Centro Nacional de Investigaciones de Café Cenicafé. Avance Técnico 465:1-12.

Jaramillo, R. I. (2011). La micorriza arbuscular (MA) centro de la rizosfera: comunidad microbiológica dinámica del suelo. Revista Contactos, 81: 17-23.

Jobim K., Goto B.T. (2016). Diversity of arbuscular mycorrhizal fungi (Glomeromycota) in maritime sand dunes of Brazilian northeast. Studies in Fungi 1(1): 43-55.

López Gómez, B. F., Alarcón, A., Quintero-Lizaola, R., y Lara-Herrera, A. (2015). Selección de cepas de hongos micorrízicos arbusculares en dos sistemas de producción de chile. Revista mexicana de ciencias agrícolas, 6(6): 1203-1214.

Neri-Luna, C., y Villarreal-Ruiz, L. (2012). Simbiosis micorrícica: un análisis de su relevante función ecosistémica y en la provisión de servicios ambientales: 37-62.

Pérez, L., H., D., Ortiz, Z., y M., N. (2015). Evaluación del uso de micorrizas en el cultivo de café (Coffea arabica) en etapa de producción en la finca El Petén comunidad Los RoblesJinotega, Nicaragua, (Doctoral dissertation, Universidad Nacional Autónoma de Nicaragua, Managua).93 p.

Peterson, R.L., Massicotte, H.B., Melville, L.H. (2004). Mycorrhizas: Anatomy and cell biology. Ottawa,Ontario: NRC Research press. CABI Publishing (pp. 1-173).

Peterson, R.L. 2010. Formulación del Proyecto: "Biofertilizantes, bioprotectores y biorestauradores Micorrícicos para la producción agroecológica en las fincas de los Productores de café" (Federación., p. 87):1-87.

Rivillas O, C.A. (2003). Las Micorrizas Arbusculares en el cultivo del café. In: Enfermedades del cafeto en Colombia. Federación Nacional de Cafeteros de Colombia. Centro Nacional de Investigaciones de Café. Editores: Luis Fernando Gil Vallejo; Bertha Lucía Castro Caicedo; Gabriel Cadena Gómez. Colombia. Agosto de 2003. P 64-74.

Rojas, Y. D. C. P., Arias, R. M., Ortiz, R. M., Aguilar, D. T., Heredia, G., y Yon, Y. R. (2018). Effects of native arbuscular mycorrhizal and phosphate-solubilizing fungi on coffee plants. Agroforestry Systems: 1-12.

Suárez Q, D.F. (2001). Evaluación de sustratos para la producción de inoculantes de micorriza vesículo-arbuscular (Bachelor's thesis, Zamorano: Escuela Agrícola Panamericana, 52p.

Trejo Aguilar, D., Ferrera Cerrato, R., Sangabriel Conde, W., Baeza, Y. (2018). Efecto de la micorriza arbuscular en plantas de café (Coffea arabica L.) infectadas por el nematodo de la corchosis de la raíz. Agro Productividad, 11(4): 1- 7.

Viasus Triana, C. (2015). Evaluación de la especificidad entre plantas e inóculos comerciales de micorrizas para el desarrollo y producción de (Pisum sativum L) (Doctoral dissertation, Corporación Universitaria Minuto de Dios).46p. 